\title{
IMPACTS OF NEOGENE-RECENT COMPRESSIONAL DEFORMATION AND UPLIFT ON HYDROCARBON PROSPECTIVITY OF THE PASSIVE SOUTHERN AUSTRALIAN MARGIN
}

\author{
S. P. Holford ', R. R. Hillis' ${ }^{1}$ I. R. Duddy'2, P. F. Green², A. K. Tuitt' and M. S. Stoker ${ }^{3}$ \\ 'Australian School of Petroleum/Centre for Tectonics, Resources and Exploration (TRaX), University of \\ Adelaide, SA 5005, Australia \\ 2Geotrack International Pty Ltd, 37 Melville Road, Brunswick West, Victoria 3055, Australia \\ ${ }^{3}$ British Geological Survey, Murchison House, West Mains Road, Edinburgh, EH9 3LA, UK \\ simon.holford@adelaide.edu.au \\ richard.hillis@adelaide.edu.au \\ mail@geotrack.com.au \\ adrian.tuitt@adelaide.edu.au \\ mss@bgs.ac.uk
}

ABSTRACT

The passive southern margin of the Australian continent, which formed following Cretaceous-Palaeogene separation from Antarctica, contains a rich record of Neogene-Recent compressional deformation and uplift. This deformation and uplift is manifested by reversal of displacement along syn-rift extensional faults, folding of mid-late Cenozoic post-rift sediments, and regional unconformities that can be traced for distances of up to $1500 \mathrm{~km}$ along the margin. Palaeothermal data from onshore and offshore exploration wells indicate that erosion associated with deformation and uplift locally exceeds $1 \mathrm{~km}$ in the eastern Otway Basin. Both neotectonic palaeostress trends inferred from these structures and present-day stress orientations are consistent with NW-SE directed compression controlled to first-order by plate boundary forces. The critical role of the relative timing of trap formation and source rock maturation in controlling hydrocarbon prospectivity in the southern Australian margin is investigated by comparing two structures that formed during Neogene-Recent deformation in the Otway Basin, the Minerva and Nerita anticlines. Whilst the Minerva Anticline hosts a major gas field (558 BCF GIP), the Nerita Anticline was found to be dry. A combination of apatite fission track analysis (AFTA), vitrinite reflectance (VR) and present-day temperature data show that all units intersected in the Minerva-1 well are currently at their maximum post-depositional temperatures, and are currently mature for hydrocarbon generation. In contrast, similar data collected from the preserved section at Nerita-1 indicate cooling from maximum post-depositional temperatures prior to formation of the Nerita Anticline in the late Miocene. Based on regional AFTA data the underlying early Cretaceous source rocks probably reached maximum palaeotemperatures and ceased hydrocarbon generation during mid-Cretaceous uplift. These results indicate that areas of the southern margin that were deformed during the Neogene-Recent have the greatest potential to trap hydrocarbons where potential source rocks are presently at their maximum post-depositional temperatures.

\section{KEYWORDS}

Passive margins, Australia, uplift, inversion, exhumation, AFTA, present-day stress, neotectonics, compressional deformation.

\section{INTRODUCTION}

As the bulk of onshore and shallow-water hydrocarbon fields have probably already been located, the hydrocarbon industry is progressively turning its attention to exploration of passive continental margins, which form following the rifting and separation of 
continental crust (White et al, 2003). Some of the largest oil field discoveries this century have been made in deep-water (>500 m) along the South American, West African and Gulf of Mexico passive margins.

The term 'passive' originates from the fact that, according to classic plate tectonic theory (e.g. Wilson, 1966), these rifted continental margins remain tectonically quiescent subsequent to their formation. They are predicted to experience no significant deformation, only exponentially decreasing subsidence as the crust and mantle cool down during the 'post-rift' stage of the their tectonic evolution (Sleep, 1971; McKenzie, 1978). However, it is being increasingly recognised that many passive margins do not show a simple pattern of uninterrupted post-rift subsidence following continental separation (Johnson et al, 2008). For example, recent studies of the NW European Atlantic passive margin have reported evidence for post-breakup (early Eocene onwards) differential subsidence, uplift, km-scale exhumation, reverse faulting and compressional folding (Lundin and Doré, 2002; Praeg et al, 2005; Stoker et al, 2005; Hillis et al, 2008a; Holford et al, 2009). These processes have exerted a major influence on the distribution and characteristics of hydrocarbon systems along this margin (Doré et al, 2002).

Another passive margin that is experiencing ongoing deformation and uplift is the southern Australian margin, which formed following late Cretaceous-Palaeogene separation of the Australian and Antarctic continents (Norvick and Smith, 2001). Seismic reflection data acquired from the Bight Basin in the west to the Gippsland Basin in the east show that this margin has locally experienced intensive compressional deformation characterized by folding, reverse faulting and pronounced angular unconformities that record km-scale uplift and erosion during the Cenozoic (Dickinson et al, 2001; Green et al, 2004; Hillis et al, 2008b). Furthermore, observations of Quaternary faulting and recent seismicity onshore southeastern Australia imply that this deformation is ongoing (Sandiford, 2003; Quigley et al, 2006).

Two of the most significant uncertainties in passive margin exploration are the thermal evolution, which controls source rock maturation, and the timing of trap formation (White et al, 2003). These two factors are directly controlled by the uplift and deformation histories of the margin respectively, and thus this paper aims to address the impacts of Neogene-Recent deformation and uplift on the distribution of hydrocarbons along the southern Australian margin (Fig. 1). We first review evidence for Neogene-Recent uplift and deformation of the southern Australian margin. We then use seismic reflection data and results from thermal history reconstruction from wells that penetrate key compressional structures in the Otway Basin (the Minerva and Nerita anticlines) to demonstrate how the relative timing of source rock maturation and trap formation exerts a critical control on the distribution of hydrocarbons. This approach indicates that areas where potential source rocks are at currently at their maximum post-depositional temperatures hold the greatest exploration potential.

\section{NEOGENE-RECENT COMPRESSIONAL DEFORMATION AND UPLIFT OF THE SOUTHERN AUSTRALIAN MARGIN}

Rifting of the southern Australian margin commenced during the Callovian ( 165-161 Ma) in western parts of the Bight Basin and progressively propagated eastwards towards the Otway and Gippsland basins by the Tithonian ( $151-145$ Ma) (Norvick and Smith, 2001). Likewise, continental break-up propagated eastwards in a diachronous manner, with seafloor spreading initiated south of the Bight Basin during the late Albian-early Campanian ( 95-83 Ma) (Tikku and Cande, 1999; Sayers et al, 2001). The exact age of the first oceanic crust formed off the Otway Basin is debated, with some suggesting that slow-spreading commenced during the Maastrichtian ( $\sim 67 \mathrm{Ma}$; Krassay et al, 2004) and others claiming that breakup occurred during the mid Eocene ( 44 Ma) coeval with the onset of fast-spreading between Australia and Antarctica (Norvick and Smith, 2001). The sedimentary successions of the southern margin become progressively more marine-influenced and calcareous throughout the Cenozoic, reflecting the progressive establishment of open marine circulation (Blevin and Cathro, 2008). Uplift and deformation during the mid-Cretaceous, intra-Maastrichtian and mid-Eocene times are reflected by a number of unconformities (Duddy et al, 2003; Krassay et al, 2004; Totterdell et al, 2004). Only the most recent phase of uplift and deformation which began during the late Miocene and continues to the present-day is addressed in the current study. This is the most easily observed of all the uplift and deformation episodes, and its origins are well understood in terms of plate boundary forces transmitted into the plate interior (Hillis et al, 2008b; Sandiford, 2003; Sandiford et al, 2004; Sandiford and Quigley, 2009).

From the perspective of hydrocarbon exploration, the Neogene-Recent deformation of the southern Australian margin is important to understand because many oil and gas-bearing structures in the Otway and particularly in the Gippsland basins formed during this time (Dickinson et al, 2001).

Most of the Neogene-Recent deformation is concentrated along southeastern parts of the margin. The Otway Basin and adjacent Torquay sub-basin contains a number of NE-SW trending folds, including several anticlines which collectively form the Otway Ranges, the Nerita Anticline, Ferguson's Hill Anticline and the Minerva Anticline, which hosts the Minerva Gas Field (558 BCF GIP; Woollands and Wong, 2001). Apatite fission-track analysis (AFTA) studies show that late Miocene exhumation in the vicinity of the Otway Ranges is of the order of $\sim 1 \mathrm{~km}$ (Green et al, 2004). These structures formed or were accentuated during the Neogene-Recent by folding above underlying syn-rift faults that have been contractionally reactivated under a NW-SE oriented compressional stress regime (Hillis et al, 2008b) (Fig. 1). Similar NE-SW striking monoclines occur throughout the onshore Gippsland Basin and include the Yallourn monocline, where a major angular unconformity separates strongly deformed Miocene sediments from mildly deformed Pliocene sediments (Hillis et al, 2008b).

In the offshore Gippsland Basin the prominent inherited structural trend is ESE, and most reverse-reactivated faults trend E-W to NE-SW (Power et al, 2003). Major hydrocarbon fields hosted in primarily Miocene-Recent structures include Barracouta, Seahorse, Flying Fish, Turrum-Morong and Tarwhine (Dickinson et al, 2001). Growth on many of these structures began during the late Oligocene, and seismic data show deformation continued into the Pliocene due to folding and reverse-offsets of late Miocene-Pliocene sediments (Dickinson et al, 2001).

Additional regional constraints on the timing of deformation are provided by a regional Miocene-Pliocene unconformity that can be traced for $\sim 1500 \mathrm{~km}$ across southeastern Australia from the Gulf St Vincent to Gippsland basins (Dickinson et al, 2002). The age of the 
unconformity is best constrained in the central Otway and Port Phillip basins where foraminiferal assemblages and strontium isotope ages indicate an age range of $\sim 10-5 \mathrm{Ma}$ (Dickinson et al, 2002). The unconformity is best imaged on seismic data in the Torquay sub-basin where in places it is highly angular (Dickinson et al, 2002).

In the Flinders and Mt Lofty Ranges of South Australia, Neogene-Recent deformation is witnessed by N-NE striking reverse faults that bound the ranges and indicate $\sim \mathrm{E}-\mathrm{W}$-directed crustal shortening as the principal cause of their uplift (Fig. 1; Sandiford, 2003; Célérier et al, 2005; Quigley et al, 2006; Hillis et al, 2008b). Exposures of these structures in the Mt Lofty (e.g. the Milendella Fault) and Flinders Ranges (e.g. the Burra, Paralana and Wilkatana Faults) reveal thrusting of Proterozoic and Lower Palaeozoic basement rocks over Miocene-Quaternary deposits (Célérier et al, 2005; Quigley et al, 2006; Hillis et al, 2008b). The near-vertical tilting of lower Miocene limestone in the footwall of the Willunga Fault $\sim 50 \mathrm{~km}$ south of Adelaide provides further evidence for post-early Miocene deformation (Sandiford, 2003). Quaternary slip rates of these reverse faults are estimated at 20-150 m Ma ${ }^{-1}$ from cumulative displacement of Pliocene and Quaternary sediments (Sandiford, 2003; Quigley et at, 2006). Ongoing deformation of the Mt Lofty and Flinders Ranges is evidenced by frequent earthquakes, which makes this region (the Flinders Seismic Zone) one of the most seismically active in Australia, along with the southeastern Australian highlands (Hillis et al, 2008b). The largest instrumentally recorded earthquakes in the Flinders Seismic Zone are $\mathrm{M} \sim 6$ (Célérier et al, 2005) whilst palaeoseismic studies have estimated maximum prehistoric earthquake magnitudes of $\mathrm{M} \sim 7.2$ (Quigley et al, 2006). Maximum seismogenic strain rates are estimated at $\sim 10^{-16} \mathrm{~s}^{-1}$ (Célérier et al, 2005), considerably higher than strain rates in comparable intraplate 'stable continental regions' like western Europe (Hillis et al, 2008b).

Earthquake focal mechanisms in the Flinders Seismic Zone indicate strike-slip and reverse mechanisms and a broadly E-W oriented present day maximum horizontal stress orientation (Clark and Leonard, 2003), consistent with E-W oriented Quaternary paleostresses inferred from the orientation of the structures that bound the ranges (Hillis et al, 2008b). In the Otway and Gippsland basins, the orientation of Neogene-Recent structures implies a NW-SE oriented maximum horizontal stress, which is consistent with present-day stress orientations determined from borehole break-outs observed in wells in these basins (Nelson et al, 2006). Plate-scale stress modelling shows that the E-W to NW-SE rotation of maximum horizontal stress orientations along the southern Australian margin (Fig. 1) is controlled to first-order by the net torques of all the plate boundary forces that act on the Indo-Australian plate (Reynolds et al, 2002; Sandiford et al, 2004; Hillis et al, 2008b). This implies that plate boundary interactions many thousands of kilometres distant drive intraplate deformation along the southern Australian margin (Hillis et al, 2008b). Dickinson et al (2002) and Sandiford et al (2004) suggest that the initiation of the stress field responsible for the Neogene-Recent deformation can be traced back to the late Miocene $(\sim 12-10$ Ma), when the formation of the Southern Alps in New Zealand led to enhanced coupling of the Australian and Pacific Plates.

The abundant evidence for Neogene-Recent deformation in southeastern Australia contrasts markedly with the apparent tectonic stability of the Bight and Eucla basins over this time interval (Hillis et al, 2008b). Seismicity levels are amongst the lowe st in any part of the Australian continent, and displacement rates on the few N-S striking faults visible on digital elevation datasets (Fig. 1) are estimated at $\sim 1 \mathrm{~m} \mathrm{Ma}^{-1}$ (Hillis et al, 2008b). Although there is little sign of structural deformation across western parts of the southern margin, the preserved stratigraphic record of the Eucla basin provides evidence for long-wavelength uplift of the southern Australia by up to several hundred metres during the Neogene-Recent. Much of the Eucla Basin is covered by the Nullabor Plain, an expansive marine limestone terrace more than $1000 \mathrm{~km}$ in length and up to $300 \mathrm{~km}$ in width that was uplifted around $15 \mathrm{Ma}$ (Sandiford, 2007). Digital elevation data show late Miocene ( $15 \mathrm{Ma}$ ) palaeo-shorelines now lie at elevations of 100-250 m ASL several hundreds of km inland (Fig. 1) (Sandiford, 2007). To the east in the Murray Basin, Pliocene shoreface strandlines that mark the maximum extent of marine incursion $\sim 6$ Myr ago when sea levels were $\sim 65 \mathrm{~m}$ above present day levels can now be found at elevations of 70-180 m ASL (Sandiford, 2007). Although the uplift of strandlines in western Victoria is locally influenced by Quaternary volcanism (Sandiford et al., 2009), Sandiford (2007) has attributed the larger record of Neogene offlap of the southern margin and stratal onlap that is observed along the northern margin of Australia to $250-300 \mathrm{~m}$ of N-down, SSW-up apparent vertical motion of the continent with respect to sea level since the mid-Miocene (Sandiford, 2007). The underlying cause of this tilting appears to be due to the NNE motion of the Australian plate, with movement of northern margin towards a dynamic topography low and geoid high associated with subduction in southeast Asia, and the southern margin off a dynamic topography and geoid low that is presently centred on the Australian-Antarctic discordance (Sandiford, 2007).

Neogene-Recent deformation has had a profound impact on the distribution of hydrocarbons along the southern margin. Many of the major hydrocarbon fields in the Gippsland Basin, such as Barracouta and Flying Fish fields, are situated in inversion anticline traps (Hillis et al, 2008b). However, wells targeting similar traps in the Torquay sub-basin have been unsuccessful, which has been ascribed to trap formation post-dating the main phase of hydrocarbon generation and migration (Hillis et al, 2008b). Here we draw comparisons between two major compressional structures - the Minerva and Nerita anticlines - to highlight the critical importance of the relative timing of trap formation with respect to source rock maturation in determining prospectivity along deformed parts of the southern margin. We characterise the thermal histories of both structures using a combination of apatite fission track analysis (AFTA), vitrinite reflectance (VR) and apatite (U-Th)/He data from the Nerita-1 and Minerva-1 wells (Fig. 2) provided by Geotrack International, and assess the chronology of their deformation using 2D seismic reflection data provided from the PGS Southern Australian Margin Digital Atlas (SAMDA) project. SAMDA is a fully integrated seismic dataset with a regional interpretation that ties together the petroleum systems of the Southern Australian Margin.

\section{GEOLOGY OF THE MINERVA AND NERITA ANTICLINES}

\section{Minerva Anticline, Shipwreck Trough}

The Minerva Anticline is located in the Shipwreck Trough in the east-central Otway Basin (Fig. 2) (Duddy and Erout, 2001). The Shipwreck Trough is a $\sim \mathrm{N}-\mathrm{S}$ trending depocentre where several significant gas discoveries have been made during the past two decades including Minerva, Thylacine, Geographe and Casino (Luxton et al, 1995; Schneider et al, 2004). The stratigraphic succession in the 
Shipwreck Trough comprises sediments whose ages range from Lower Cretaceous to Recent (Fig. 3). The oldest penetrated sediments are Eumeralla Formation (Albian) fluvio-lacustrine sequences, although older members of the Otway Group are inferred to be present from seismic data (Sharp and Wood, 2004). The Otway Group sequences are sufficiently organic rich to be considered the primary hydrocarbon source rocks for reservoir targets in the Shipwreck Trough (Sharp and Wood, 2004). The Otway Group is separated by a regional midCretaceous unconformity from the overlying Upper Cretaceous Sherbrook Group (Duddy, 2003). The Sherbrook Group contains the main reservoir (Waarre Formation) and sealing (Flaxman Formation and Belfast Mudstone) horizons in the Shipwreck Trough (Duddy and Erout, 2001; Sharp and Wood, 2004). The Sherbrook Group is successively overlain by the clastic Palaeocene to mid Eocene Wangerrip Group, the clastic late Eocene to early Oligocene Nirranda Group and the carbonate late Oligocene-Recent Heytesbury Group (Sharp and Wood, 2004).

A $\sim$ NE-SW trending seismic reflection profile through the Minerva Anticline that ties the Minerva-2A and La Bella-1 wells is shown in Figure 4, provided courtesy of PGS. The interpretation is based on regional mapping of unconformities of mid-Cretaceous, intraMaastrichtian, intra-Lutetian and intra-Oligocene age in the Shipwreck Trough. It is immediately apparent that the Minerva Anticline is an inverted half-graben basin in which reverse-reactivation of the normal faults that accommodated deposition of the Sherbrook Group has caused folding of the overlying Wangerrip, Nirranda and Heytesbury Groups. Based on 3D seismic mapping of the Minerva Anticline, Schneider et al (2004) identified an initial phase of compressional growth during the Campanian-Palaeocene, but significant MioceneRecent growth on the structure is also consistent with the folding of the top Nirranda Group (intra-Oligocene) unconformity (Fig. 4).

The Minerva-1 well was drilled in 1993 to test Waarre Formation closure within the Minerva Anticline (Geary and Reid, 1998). The well is located in $57 \mathrm{~m}$ water depth $\sim 7 \mathrm{~km}$ off the coast of Victoria and reached a total drilled depth of $2410 \mathrm{~m}$. The well penetrated a typical Otway basin sequence of Heytesbury, Nirranda, Wangerrip and Sherbrook Groups each separated by unconformities, with a thin Eumeralla Formation sequence intersected near TD. Wireline logs and repeat formation tests (RFT) indicated the presence of two hydrocarbon -bearing sandstones (10 m and $15 \mathrm{~m}$ gross) in the upper part of the Flaxman Formation and a gross gas column of $133 \mathrm{~m}$ in the Waarre Formation (Geary and Reid, 1998). The Minerva-2A well was later drilled in the southernmost fault block of the Minerva Anticline as an appraisal well to the Minerva-1 discovery and intersected a $111 \mathrm{~m}$ thick gas column (Geary and Reid, 1998).

\section{Nerita Anticline, Torquay sub-basin}

The Nerita Anticline is a NE-SW trending structure in the mostly offshore Torquay sub-basin (Fig. 2). The basin contains up to 7 $\mathrm{km}$ of Cretaceous-Neogene sediments (Fig. 3) and is bounded to the northwest and southeast by the Otway Ranges and Mornington Peninsula, respectively, two NE-SW-trending structural highs that witnessed compression, uplift and exhumation during both the midCretaceous and late Cenozoic (Dickinson et al, 2002; Green et al, 2004).

The Lower Cretaceous Eumeralla Formation succession of the Torquay sub-basin (comprising the Eumeralla Formation) is similar to that in the Shipwreck Trough (Fig. 3), but the stratigraphy above the regional mid-Cretaceous unconformity shares a closer affinity with the Bass Basin to the east. In the Torquay sub-basin this unconformity represents a time gap of $\sim 20$ Myr (Messent et al, 1999) and is overlain by the Upper Cretaceous (Campanian) to mid Eocene Eastern View Group that consists of interbedded lower coastal plain sandstones, siltstones, shales and coals deposited in a dominantly fluvial environment (Trupp et al, 1994; Messent et al, 1999). Above a regional mid Eocene unconformity, the Eastern View Group is succeeded by the late Eocene to early Oligocene Demons Bluff Group. This group includes a basal transgressive sandy unit called the Boonah Formation, overlain by the Anglesea siltstone and the regressive, sandy Anghaook Formation (Messent et al, 1999). The Anglesea Siltstone provides the seal for reservoir targets in the Boonah Formation (Messent et al, 1999). The Oligocene-Miocene Torquay Group commenced deposition with the onset of Oligocene transgression resulting in calcareous sediments being deposited under widespread marine conditions.

The Nerita Anticline is one of several NE-SW trending anticlines that have been targets for hydrocarbon exploration, but none of the three wells drilled in the basin to-date (Nerita-1, Snail-1 and Wild Dog-1) have discovered commercial accumulations (Trupp et al., 1994). Figure 5 shows a NNW-SSE trending seismic reflection profile through the Nerita Anticline that ties the Nerita-1 and Snail-1 wells, provided courtesy of PGS. The structure of the Nerita Anticline is broadly similar (albeit oriented differently) to the Minerva Anticline. Reverse reactivation of the normal faults that provided accommodation space for the syn-rift Jurassic-Eocene Otway and Eastern View Groups has resulted in folding of the overlying post-rift Eocene-Miocene Demons Bluff and Torquay groups. These units exhibit consistent thicknesses across the structure, indicating that formation of the Nerita Anticline post-dates the youngest preserved stratigraphy penetrated by Nerita-1 (Puebla Formation, $\sim 15 \mathrm{Ma}$ ). Much of the seismicity in the Torquay sub-basin is concentrated on the Nerita Anticline, indicating that deformation and growth on the structure may be continuing to the present-day.

Nerita-1 was drilled into the crest of the Nerita Anticline in $74.7 \mathrm{~m}$ of water and reached a TD of $2042 \mathrm{~m}$. The well encountered sediments from the Torquay, Demons Bluff, Eastern View and Otway groups separated by unconformities. It was designed to test reservoir sands in the Boonah Formation sealed by the regional Anglesea Siltstone seal (both Demons Bluff Group) (Trupp et al, 1994). Similarly to the Shipwreck Trough, Eumeralla Formation shales are the presumed source rock in the Torquay sub-basin (Trupp et al, 1994). Gas readings in the basal Eastern View Group and in the Eumeralla Formation are dominantly associated with coals, although gas peaks of up to $18 \%$ were reported from permeable, coal-free argillaceous sandstones in the Eumeralla Formation (Messent et al, 1999). Reservoir quality in the target Boonah Formation is excellent with porosity of the order of $25-31 \%$, although no shows were reported at that level (Messent et al, 1999). The Anglesea Siltstone provides the regional seal to the principal reservoir objectives (Eocene Boonah Formation) in the Torquay sub-basin (Trupp et al, 1994). It ranges in thickness from $120 \mathrm{~m}$ to greater than $300 \mathrm{~m}$ (Trupp et al, 1994). The general lack of shows in the underlying reservoir units prompted quantitative evaluation of the seal potential of the Anglesea Siltstone (Trupp et al, 1994). The membrane seal capacity of sidewall samples from well Wild Dog-1 was analysed using mercury injection porosimity which indicated that the Anglesea Siltstone can have a sealing capacity for an oil or gas column of several hundred metres (Trupp et al, 1994). Seismic surveys show closure at the primary reservoir at Nerita-1 (Messent et al, 1999). Consequently, seal quality is not considered to be the cause 
of failure for Nerita-1, with Messent et al (1999) concluding that the most likely reason for failure is associated with the timing of expulsion and migration of hydrocarbons in relation to the timing of trap formation. We seek to test this explanation by reconstructing the thermal history of the Nerita-1 well, and comparing it with that of the successful Minerva-1 well.

\section{PRINCIPLES OF THERMAL HISTORY RECONSTRUCTION}

AFTA and VR data provide independent but complementary constraints on the low temperature thermal histories of sedimentary rocks. The combined application of these techniques to a vertical sequence of samples (e.g. over a range of depths in an exploration well) enables quantitative determination of palaeogeothermal gradients. If it can be determined that the cause of heating is deeper burial, these data can be used to estimate the amount of additional burial responsible for heating.

The methodological, analytical and interpretative aspects of AFTA and VR data are well-known (e.g. Green et al, 2002; Crowhurst et al, 2002; Turner et al, 2008) and are not repeated in detail here. AFTA exploits the spontaneous fission of ${ }^{238} \mathrm{U}$ atoms in apatite, and the temperature-dependent annealing of the resultant radiation damage zones (fission tracks). It can be used to define the magnitude of post-depositional heating of apatite-bearing sedimentary rocks and the timing of cooling from maximum post-depositional temperatures of up to $\sim 110^{\circ} \mathrm{C}$ (Green et al, 2002). To extract thermal history information from AFTA data we employ a kinetic model that makes full quantitative allowance for the effects of $\mathrm{Cl}$ content on fission-track annealing rates (Green et al, 2002). Because maximum palaeotemperatures are the key factor that dominates AFTA data, this technique can reveal little information on the thermal history prior to the onset of cooling. Therefore, we do not attempt to constrain the entire thermal history of each sample but focus on the key aspects of the thermal history that control the fission track age and length distribution i.e. the maximum palaeotemperature of each sample and the time at which cooling from that palaeotemperature began.

For samples that have been hotter in the past, by comparing measured AFTA parameters with values predicted from a range of possible scenarios, maximum likelihood theory (similar to that described by Gallagher (1995)) is used to define best-fit values of maximum palaeotemperature and the time at which cooling begins. Systematically varying the timing of the onset of cooling and the peak palaeotemperature about the best-fit values allows us to rigorously define the range of conditions which give predictions that are consistent with the measured data within $95 \%$ confidence limits for up to two (or rarely three) separate thermal episodes. Palaeotemperature estimates derived using this approach usually have an absolute uncertainty of better than $\pm 10^{\circ} \mathrm{C}$.

VR is based on the increase in reflectivity of vitrinite (an organic maceral and a key constituent of coal) with te mperature. The kinetics of this process are well understood and very similar to those of fission track annealing in apatite (Duddy et al, 1998), and in this study we utilize the model of Burnham and Sweeney (1989) to convert values of observed maximum reflectance under oil $\left(R_{0}\right.$ max) to palaeotemperatures. VR is highly complementary to AFTA because vitrinite is commonly found in fine-grained sedimentary rocks (apatite is generally found in sandstones) and because in can constrain maximum palaeotemperatures that far exceed (i.e. $>300^{\circ} \mathrm{C}$ ) the upper limit of the AFTA technique.

We have also performed apatite (U-Th)/He dating on one sample from Nerita-1. This method can potentially constrain the thermal histories of sediments in the $40-80^{\circ} \mathrm{C}$ range by exploiting the interplay between the accumulation of He within the apatite lattice by alpha decay of $U$ and Th isotopes, and the loss of He due to diffusion, which occurs at a rate dependent on temperature and grain size (Crowhurst et al, 2002). Further analytical and interpretive details of the application of apatite (U-Th)/He dating to sedimentary basins are provided by Crowhurst et al (2002) and Green et al (2004).

\section{THERMAL HISTORY OF THE MINERVA ANTICLINE}

Three AFTA samples and 12 VR samples were available for this well. Basic AFTA parameters (fission track age, mean track length), VR $\left(R_{0} \max \right)$ values and palaeotemperature estimates are provided in Table 1. Figure 6a shows a temperature-depth plot with palaeotemperatures estimated from AFTA and VR samples compared with the present-day geothermal gradient at this location. Three corrected bottom hole temperature (BHT) measurements at $1189 \mathrm{~m}, 2019 \mathrm{~m}$ and $2419.5 \mathrm{~m}$ gave corrected temperatures of $66.6,100$ and $108.8^{\circ} \mathrm{C}$ respectively, constraining the present-day geothermal gradient of $42.2^{\circ} \mathrm{C} \mathrm{km}^{-1}$ (assuming a seabed temperature of $15^{\circ} \mathrm{C}$ ). This value is a little higher than regional Otway gradients which are typically between 30 and $35^{\circ} \mathrm{C} \mathrm{km}^{-1}$ (Duddy and Erout, 2001), but the corrected values are very consistent and there appears to be no reason to see this gradient as anomalous. It may be the case that the average thermal conductivities of the mud-rich Upper Cretaceous-Cenozoic drilled section at Minerva-1 are lower than elsewhere in the basin, with average geothermal gradients in the Otway Basin biased towards wells that have been drilled in the Eumeralla Formation.

By comparing the present-day temperatures with the palaeotemperatures determined from AFTA and VR it is clear that the sampled Sherbrook Group and Eumeralla Formation sections are at or close to their maximum post-depositional temperatures at the present-day (Fig. 6a). Although the AFTA data would allow heating to temperatures as high as $90^{\circ} \mathrm{C}$ to $120^{\circ} \mathrm{C}$ during the past 50 Myr or $105^{\circ} \mathrm{C}$ to $130^{\circ} \mathrm{C}$ at some time post-deposition (Table 1), the simplest explanation of all data is that the preserved section is currently at or near maximum post-depositional temperatures. This is confirmed by palaeotemperatures estimated from VR data, which are highly similar to the present-day temperatures estimated from BHT data. The deepest VR sample, obtained from near the top of the Eumeralla Formation, gave a $R_{0}$ max value of $0.75 \%$, indicating that this formation is mature for hydrocarbon generation at the present-day.

Assuming that the geothermal gradient has remained constant over time, no significant erosion is required on any of the major unconformities within the preserved section to explain the AFTA and VR data (Scenario 1 in Fig. $6 \mathrm{c}$ and d). A cross plot of allowed (but not required) total section removed from the top-Heytesbury Group unconformity in the Minerva-1 well against palaeogeothermal gradient shows the range of values of these parameters which are compatible with the maximum palaeotemperatures derived from AFTA and VR data at the $95 \%$ confidence level (Fig. 6b). For a palaeogeothermal gradient of $42.2^{\circ} \mathrm{C} \mathrm{km}^{-1}$ (equal to the present-day value) no removed 
section is required on the top-Heytesbury Group unconformity in order to honour constraints from AFTA and VR. Around 350 m of erosion at the top Heytesbury Group unconformity ( $\sim 15 \mathrm{Ma})$ is allowed by the AFTA and VR data (Fig. 6b), but only if the geothermal gradient has increased over time from $35^{\circ} \mathrm{C} \mathrm{km}^{-1}$ prior to the mid Miocene to its present-day value of $42.2^{\circ} \mathrm{C} \mathrm{km}^{-1}(\mathrm{Scenario} 2$ in Fig. $6 \mathrm{e}$ and $\mathrm{f}$ ). Even higher magnitudes of removed section are allowed by the results, but only when combined with values of palaeogeothermal gradient that are substantially lower than the present-day gradient. Thus, while uplift and erosion associated with the development of the top-Heytesbury Group unconformity is allowed by AFTA and VR results, significant erosion requires significantly lower palaeo-heat flow.

AFTA, VR and present-day temperature data from Minerva-1 thus suggest that active source rock maturation from potential Eumeralla Formation source rocks is most likely occurring at the present-day, post-dating formation of the trapping Minerva Anticline structure (cf. Duddy and Erout, 2001).

\section{THERMAL HISTORY OF THE NERITA ANTICLINE}

Two AFTA samples, one apatite (U-Th)/He sample and 14 VR samples were analysed from Nerita-1. Full analytical details and palaeotemperature interpretations for these samples are provided in Table 2. A palaeotemperature-depth plot based on interpretation of AFTA, VR and (U-Th)/He samples shows that maximum post-depositional temperatures encountered by the preserved section are around $30^{\circ} \mathrm{C}$ higher than present-day temperatures throughout the well (Fig.7a). A single corrected BHT data point near TD constrains the presentday geothermal gradient at this location to $\sim 31.5^{\circ} \mathrm{C} \mathrm{km}^{-1}$ (assuming a seabed temperature of $15^{\circ} \mathrm{C}$ ). The similarity between the slope of the present-day geothermal gradient and the palaeotemperature profile inferred from thermal history data indicates that the cause of the observed heating was most likely deeper burial (followed by cooling due to uplift and erosion) rather than a period of elevated heat flow. A few palaeotemperatures estimated from the VR plot below the trend of the majority of the VR and AFTA results, possibly due to caving contamination for the deeper samples (noted during analyses) or some form of suppression of the true VR levels (presumably in the shallowest sample). These data have not been used in the quantitative analysis. Combined thermal history interpretation of AFTA and (U$\mathrm{Th}$ )/He data indicates that the drilled section began to cool from maximum post-depositional temperatures between 10 and $5 \mathrm{Ma}$ (coeval with the time interval represented by the regional Miocene-Pliocene unconformity (Dickinson et al, 2002)).

Figure $7 \mathrm{~b}$ shows the allowed values of palaeogeothermal gradient and missing section removed from the Torquay Group that are required to explain the observed late Miocene palaeotemperatures. The maximum likelihood estimate of palaeogeothermal gradient is $24.5^{\circ} \mathrm{C} \mathrm{km}^{-1}$ and the allowed range of values within $95 \%$ confidence limits (as determined using maximum likelihood theory) is 13.5 to $36.5^{\circ} \mathrm{C} \mathrm{km}^{-1}$ (Fig. 7b). The allowed range of palaeogeothermal gradients encompasses the present-day geothermal gradient of $31.5^{\circ} \mathrm{C} \mathrm{km}{ }^{-1}$ and confirms the observed palaeotemperatures are best explained in terms of deeper burial of the preserved section prior to late Miocene uplift and erosion. For a palaeogeothermal gradient equivalent to the present-day gradient, between 940 and $1260 \mathrm{~m}$ of deeper burial by additional Torquay Group section is required to explain the late Miocene palaeotemperatures (Fig. 7b).

These results indicate that active source rock maturation, and thus hydrocarbon generation from any potential Eumeralla Formation source rocks in the Nerita-1 drilled section ceased with cooling that accompanied uplift beginning between 10 and 5 Ma. Measured and equivalent (from AFTA) VR values near the base of Nerita- 1 are in the range of $\sim 0.5$ to $0.6 \%$ ( $\mathrm{R}_{0}$ max) which is consistent with very early maturity for oil. Scenario 1 in Figure $7 \mathrm{c}$ and d presents our preferred thermal and burial history reconstructions for Nerita-1 based on available data. This burial history incorporates $1050 \mathrm{~m}$ of additional section attributed to the Miocene Puebla Formation subsequently removed by uplift and erosion beginning at $8 \mathrm{Ma}$ and completed prior to the Pliocene.

AFTA, VR and (U-Th)/He results from Nerita-1 provide no direct information on the magnitude of any erosion on the deeper, top-Otway Group unconformity, but allow limits to be placed when combined with regional thermal history constraints. AFTA and VR data available from the onshore Anglesea-1 well (Green et al, 2004), which penetrated a considerably thicker ( 2.5 km) Otway Group succession than Nerita-1, enable the maturity levels and likely hydrocarbon generation history of the underlying Eumeralla Formation at Nerita-1 to be assessed. These data indicate that maximum post-depositional heating of the preserved Eumeralla Formation occurred prior to mid-Cretaceous cooling and exhumation that began between 100 and $90 \mathrm{Ma}$ (Green et al, 2004). The inferred palaeogeothermal gradient prior to this cooling and exhumation episode (which removed $\sim 2 \mathrm{~km}$ of additional Otway Group section) was $\sim 50^{\circ} \mathrm{C} \mathrm{km}{ }^{-1}$, considerably higher than the present-day gradient $\left(36^{\circ} \mathrm{C} \mathrm{km}^{-1}\right)$. Measured VR values from the Otway Group vary from $0.76 \%$ at $592 \mathrm{~m}(\mathrm{below} \mathrm{kb})$ to $3.38 \%\left(\mathrm{R}_{\mathrm{o}} \max \right)$ at $3065 \mathrm{~m}$ near TD (Green et al, 2004). These results indicate that the combined effects of deeper burial and elevated heat flow during the mid-Cretaceous led to generation of hydrocarbons from Lower Cretaceous source rocks prior to 100 to $90 \mathrm{Ma}$ uplift and erosion, and decline in heat flow (Green et al, 2004). Based on results from Anglesea-1 and other wells in the Otway Basin (e.g. Duddy, 1997; 2003), we consider it likely that the Lower Cretaceous succession beneath Nerita-1 similarly experienced maximum postdepositional temperatures and generated hydrocarbons prior to mid-Cretaceous ( 100-90 Ma) uplift and erosion, significantly earlier than the timing of deformation and trap formation ( 10-5 Ma). Our preferred scenario for the burial and thermal history of Nerita-1 is outlined in Figure 7e and $\mathrm{f}$. The depicted burial history incorporates the same late Miocene event incorporated in Scenario 1, but also incorporates $1200 \mathrm{~m}$ of section removed on the top Otway unconformity, in accord with regional data (e.g. AFTA and VR from Anglesea-1).

\section{CONTROLS ON THE RELATIVE TIMING OF TRAP FORMATION AND SOURCE ROCK MATURATION}

AFTA and VR data from the Minerva and Nerita anticlines indicate that the relative timing of trap formation and source rock maturation can explain the relative success and failure of the wells that drilled these structures, both of which underwent growth during the late Miocene-early Pliocene. Lower Cretaceous Eumeralla Formation (Otway Group) shales and coals provide the probable source rock at both locations. Thermal history data indicate that source rocks in the Minerva Anticline are at maximum post-depositional temperatures and 
are generating hydrocarbons at the present-day. However, data from the Nerita Anticline suggest that Eumeralla Formation source rocks experienced maximum post-depositional temperatures and generated hydrocarbons $\sim 100-90 \mathrm{Ma}$, considerably earlier than the timing of trap formation ( 10-5 Ma). Reservoir quality and/or seal integrity are not considered to be contributing factors to the failure of the Nerita-1 well (Messent et al, 1999). Measured porosities in the target Boonah Formation are of the order of 25-31\% (Messent et al, 1999). Seismic reflection data show closure at the top of the Boonah Formation (Messent et al, 1999), and mercury injection analysis of sidewall samples of the regional Anglesea Siltstone seal horizon at the nearby Wild Dog-1 well indicate sealing capacity for an oil or gas column of several hundred metres (Trupp et al, 1994). These observations reaffirm our conclusions, based on AFTA and VR data, that the relative timing of trap formation and source rock maturation can explain the failure of the Nerita-1 well.

Trap formation and source rock maturation are both controlled by the burial, uplift and deformation histories of a particular location, and it is thus necessary to consider the causes of the different geological histories of the Minerva and Nerita anticlines. During the early Cretaceous, the Shipwreck Trough and Torquay-sub basin were both part of a major continental rift system that encompassed the Otway, Bass and Gippsland basins (Duddy, 2003). At the end of the early Cretaceous ( 95 Ma), some parts of this rift system, including the Torquay sub-basin and the adjacent Otway Ranges experienced major uplift and erosion related to compressional deformation that reactivated earlier extensional faults (Hill et al, 1995; Duddy, 2003). AFTA and VR data from wells and outcrops in the Otway Basin suggest that heat flow at $\sim 95 \mathrm{Ma}$ was approximately double present-day levels, and then declined rapidly, reaching present-day levels at $\sim 80 \mathrm{Ma}$ (Duddy, 2003). This episode of uplift, erosion and elevated heat flow is recorded by AFTA and VR data from the Anglesea-1 well (Green et al, 2004) and is inferred to have occurred at Nerita-1. Although the top-Otway Group unconformity associated with the 95 Ma event is found throughout the Otway Basin, it is clear that uplift and deformation was far less severe in the Shipwreck Trough and regions further to the west (Duddy, 2003). Whereas the Torquay sub-basin and Otway Ranges likely remained as structural highs, with late Cretaceous sediments thin or absent, in the Shipwreck Trough rifting and sedimentation resumed by the Turonian and continued throughout the late Cretaceous (Duddy, 2003; Schneider et al, 2004).

During the late Miocene-early Pliocene, the Minerva and Nerita anticlines both experienced compression, producing the trapping structures at both locations. However, whilst thermal history data indicate $\sim 1 \mathrm{~km}$ of erosion at Nerita-1 (Fig. 7b), AFTA and VR data indicate far less erosion at Minerva-1. A maximum of $350 \mathrm{~m}$ at the top Heytesbury Group unconformity is allowed by these data, and the simplest explanation of the AFTA and VR data requires no erosion (Fig. 6b). The lack of significant late Miocene-early Pliocene erosion at the Minerva Anticline has allowed the Eumeralla Formation source rocks to continue generating hydrocarbons and charge the structure with gas at the present-day. There are several explanations for the different amounts of late Miocene-early Pliocene erosion observed at Minerva-1 and Nerita-1. One possibility is that the bathymetry in the Shipwreck Trough during the late Miocene-early Pliocene was deeper than that in the Torquay sub-basin, meaning that folding-related uplift at the Minerva Anticline generated lesser subaerial relief and lower erosion than at the Nerita Anticline. Alternatively, lower amounts of erosion at the Minerva Anticline may reflect less deformation at that location in comparison to the Minerva Anticline, because of the relative orientations of the underlying structural trends to the prevailing stress field. The predominant, NE-SW structural trend in the Torquay sub-basin (Trupp et al, 1994) is orthogonal to the $\sim$ NW-SE presentday maximum horizontal stress orientation in the Otway Basin (Nelson et al, 2006), which is inferred to have initiated in the late Miocene (Dickinson et al, 2002; Sandiford et al, 2004). Although the Minerva Anticline has a $\sim$ NNE-SSW orientation, it is located within the $\sim$ N-S trending Shipwreck Trough, which is more oblique with respect to the inferred late Miocene stress field. Since major structures in the Torquay sub-basin are more suitably oriented for reactivation than the Shipwreck Trough it is possible that the former region accommodated more deformation during the late Miocene-early Pliocene, thereby resulting in higher levels of uplift and erosion at the Nerita Anticline.

\section{IMPLICATIONS FOR HYDROCARBON PROSPECTIVITY}

The contrasting levels of exploration success in the Shipwreck Trough and Torquay sub-basin, and between the Minerva and Nerita anticlines, both of which have experienced Neogene-Recent compressional deformation, can be understood in terms of the relative timing of trap formation and source rock maturation and hydrocarbon generation. Whilst the preserved section at Minerva-1 is at maximum post-depositional temperatures at the present-day, which enables ongoing charge of the structure, the formation of the Nerita Anticline postdates the main episodes of hydrocarbon generation and migration. These findings highlight the critical importance of determining the relative chronologies of trap formation and hydrocarbon generation along uplifted and deformed passive margins such as that of southern Australia. Whereas we have focussed on the Neogene-Recent history of the margin, it is apparent that there have also been earlier phases of deformation, such as that during the mid-Eocene that produced the Morum High structure (removing $\sim 1,500 \mathrm{~m}$ of Palaeocene-Eocene Wangerrip Group) in the western Otway Basin (Duddy et al, 2003). We suggest that the best potential for hydrocarbon occurrence in parts of the southern Australian margin that were deformed during the Neogene-Recent or earlier exists where potential source rocks are at their maximum post-depositional temperature now (cf. Duddy, 1997) and recommend that future studies focus their attention on defining the spatial distribution of such areas.

\section{ACKNOWLEDGMENTS}

This work was supported by ARC Discovery Project DP0879612 and forms TRaX contribution \#73. Adam Smith, Iain Brown and Huw Edwards of PGS are gratefully acknowledged for provision of SAMDA and permission to publish Figures 4 and 5 . The contribution of Stoker is made with the permission of the Director of the British Geological Survey (Natural Environment Research Council). 


\section{REFERENCES}

BLEVIN, J. AND CATHRO, D. 2008-Australian Southern Margin Synthesis. Project GA707, Client report to Geoscience Australia by FrOG Tech Pty Ltd.

BURNHAM, A.K. AND SWEENEY, J.J. 1989-A chemical kinetic model of vitrinite reflectance maturation. Geochimica et Cosmochimica Acta, 53, 2649-2657.

CÉLÉRIER, J., SANDIFORD, M., HANSEN, D.L. AND QUIGLEY, M., 2005-Modes of active intraplate deformation, Flinders ranges, Australia. Tectonics, 24 (6), 10.1029/2004TC001679.

CLARK, D. AND LEONARD, M., 2003-Principal stress orientations from multiple focal-plane solutions: new insight into the Australian intraplate stress field. In: Hillis, R.R. and Muller, R.D. (eds) Evolution and Dynamics of the Australian Plate, GSAm Special Publication 22 and GSA Special Paper 372, 91-105.

CONSTANTINE, A. AND LIBERMAN, N. 2001-Hydrocarbon prospectivity package for VIC/O-01(1), VIC/O-01(2) AND VIC/O-01(3), eastern onshore Otway Basin, Victoria, Australia: 2001 acreage release, Victorian Initiative for Minerals and Petroleum Report 70.

CROWHURST, P.V., GREEN, P.F. AND KAMP, P.J.J. 2002-Appraisal of (U-Th)/He apatite thermochronology as a thermal history tool for hydrocarbon exploration: an example from the Taranaki Basin, New Zealand. AAPG Bulletin, 86, 1801-1819.

DICKINSON, J.A., WALlACE, M.W., HOLDGATE, G.R., DANIELS, J., GALlAGHER, S.J. AND THOMAS, L. 2001-Neogene tectonics in SE Australia: implications for petroleum systems. The APPEA Journal, 51, 37-52.

DICKINSON, J.A., WALLACE, M.W., HOLDGATE, G.R., GALLAGHER, S.J. AND THOMAS, L., 2002-Origin and timing of the Miocene-Pliocene unconformity in southeast Australia. Journal of Sedimentary Research, 72 (2), 288-303.

DORÉ, A.G., CORCORAN, D.V. AND SCOTCHMAN, I.C. 2002-Prediction of the hydrocarbon system in exhumed basins, and application to the NW European margin. In: Doré, A.G., Cartwright, J.A., Stoker, M.S., Turner, J.P. and White, N. (eds) Exhumation of the North Atlantic margin: timing, mechanisms and implications for petroleum exploration, GSL, Special Publication 196, 401-429.

DUDDY, I.R. 1997-Focussing exploration in the Otway Basin: understanding timing of source rock maturation. The APPEA Journal, 37 (1), 178-191.

DUDDY, I.R. 2003-Mesozoic, a time of change in tectonic regime. In: Birch, W.D. (ed) Geology of Victoria, GSA Special Publication 23, 239-286.

DUDDY, I.R. AND EROUT, B. 2001-AFTA ${ }^{\circledR}$-calibrated 2-D modelling of hydrocarbon generation and migration using Temispack ${ }^{\circledR}$ : preliminary results from the Otway Basin. In: Hill, K.C. and Bernecker, T. (eds) Eastern Australian Basins Symposium, A refocussed energy perspective for the future, PESA, Special Publication, 485-497.

DUDDY, I.R., GREEN, P.F., HEGARTY, K.A., BRAY, R.J. AND O'BRIEN, G.W. 1998-Dating and duration of hot fluid flow events determined using AFTA $^{\circledR}$ and vitrinite reflectance-based thermal history reconstruction. In: Parnell, J. (ed) Dating and Duration of Fluid Flow and Fluid-Rock Interaction, GSL, Sepcial Publication 144, 41-51.

DUDDY, I.R, EROUT, B., GREEN, P.F., CROWHURST, P.V. AND BOULT, P.J. 2003-Timing constraints on the structural history of the western Otway Basin and implications for hydrocarbon prospectivity around the Morum High, South Australia. The APPEA Journal, $53,59-83$.

FARLEY, K.A. 2000-Helium diffusion from apatite: general behaviour as illustrated by Durango flourapatite. Journal of Geophysical Research, 105B, 2903-2914.

FARLEY. K.A., WOLF. R.A. AND SILVER. L.T. 1996-The effects of long alpha-stopping distances on (U-Th)/He ages. Geochimica et Cosmochimica Acta, 60, 4223-4229.

GALBRAITH, R.F. AND LASLETT, G.M. 1993-Statistical methods for mixed fission track ages. Nuclear Tracks, 21, 459-470.

GALLAGHER, K. 1995-Evolving temperature histories from apatite fission-track data. Earth and Planetary Science Letters, 136, $421-435$.

GEARY, G.C. AND REID, I.S.A. 1998-Geology and prospectivity of the offshore eastern Otway Basin, Victoria-for the 1998 acreage release, Victorian Initiative for Minerals and Petroleum Report 55. 
GREEN, P.F., DUDDY, I.R. AND HEGARY, K.A. 2002-Quantifying exhumation in sedimentary basins of the UK from apatite fission track analysis and vitrinite reflectance data: precision, accuracy and latest results. In: Doré, A.G., Cartwright, J.A., Stoker, M.S., Turner, J.P. and White, N. (eds) Exhumation of the North Atlantic margin: timing, mechanisms and implications for petroleum exploration, GSL, Special Publication 196, 331-354.

GREEN, P.F., CROWHURST, P.V. AND DUDDY, I.R. 2004-Integration of AFTA and (U-Th)/He thermochronology to enhance the resolution and precision of thermal history reconstruction in the Anglesea-1 well, Otway Basin, SE Australia. In: Boult, P.J., Johns, D.R. and Lang, S.C. (eds) Eastern Australian basins symposium II, PESA Special Publication, 117-131.

HILL, K.C., HILL, K.A., COOPER, G.T., O’SULLIVAN, A.J., O’SULliVAN, P.B. AND RICHARDSON, M.J. 1995-Inversion around the Bass Basin, SE Australia. In: Buchanan, J.G. and Buchanan, P.G. (eds) Basin Inversion, GSL, Special Publication 88, $525-547$.

HILliS, R.R., HOLFORD, S.P., GREEN, P.F., DORÉ, A.G., GATLIFF, R.W., STOKER, M.S., THOMSON, K., TURNER, J.P., UNDERHILL, J.R. AND WILLIAMS, G.A. 2008a-Cenozoic Exhumation of the southern British Isles. Geology, 36 (5), $371-374$.

HILLIS, R.R., SANDIFORD, M., REYNOLDS, S.D. AND QUIGLEY, M.C. 2008b-Present-day stress, seismicity and Neogene-to-Recent tectonics of Australia's 'passive' margins: intraplate deformation controlled by plate boundary forces. In: Johnson, H., Doré, A.G., Gatliff, R.W., Holdsworth, R., Lundin, E.R. and Ritchie, J.D. (eds) The nature and origin of compression in passive margins, GSL, Special Publication 306, 71-90, 10.1144/SP306.3.

HOLDGATE, G.R., WALlACE, M.W., GALlAGHER, S.J., WAGSTAFF, B.E. AND MOORE, D. 2008-No mountains to snow on: major post-Eocene uplift of the East Victoria highlands; evidence from Cenozoic deposits. Australian Journal of Earth Sciences, 55, 211 $234,10.1080 / 08120090701689373$.

HOLFORD, S.P., GREEN, P.F., DUDDY, I.R., TURNER, J.P., HILLIS, R.R. AND STOKER, M.S. 2009-Regional intraplate exhumation episodes related to plate boundary deformation. GSA Bulletin, 121 (11-12), 1611-1628, 10.1130/B26481.

HURFORD, A.J.H. AND GREEN, P.F. 1983-The zeta age calibration of fission-track dating. Chemical Geology (Isotope Geoscience Section), 1, 285-317.

JOHNSON, H., DORÉ, A.G., GATLIFF, R.W., HOLDSWORTH, R., LUNDIN, E.R. AND RITCHIE, J.D. 2008-The nature and origin of compression in passive margins, GSL, Special Publication 306.

KRASSAY, A.A., CATHRO, D.L. AND RYAN, D.J. 2004-A regional tectonostratigraphic framework for the Otway Basin. In: Boult, P.J., Johns, D.R. and Lang, S.C. (eds) Eastern Australian basins symposium II, PESA Special Publication, 97-106.

LEONARD, M. 2008-One hundred years of earthquake recording in Australia. Bulletin of the Seismological Society of America, 98, 1458$1470,10.1785 / 0120050193$.

LUNDIN, E.R. AND DORÉ, A.G. 2002-Mid-Cenozoic post-breakup deformation in the 'passive' margins bordering the NorwegianGreenland Sea. Marine and Petroleum Geology, 19, 79-93.

LUXTON, C.W., HORAN, S.T., PICKAVANCE, D.L. AND DURHAM, M.S. 1995-The La Bella and Minerva gas discoveries, offshore Otway Basin. The APEA Journal, 35, 405-417.

McKENZIE, D. 1978-Some remarks on the development of sedimentary basins. Earth and Planetary Sciences Letters, 40, 25-32.

MESSENT, B.E., COLLINS, G.I. AND WEST, B.G. 1999-Hydrocarbon prospectivity of the offshore Torquay sub-basin, Victoria: gazettal area V99-1, Victoria Initiative for Minerals and Petroleum 60.

NELSON, E.J., HILLIS, R.R., SANDIFORD, M., REYNOLDS, S.D. AND MILDREN, S.D. 2006-Present-day state-of-stress of southeast Australia. The APPEA Journal, 46, 283-305.

NORVICK, M.S. AND SMITH, M.A. 2001-Mapping the plate tectonic reconstruction of southern and southeastern Australia and implications for petroleum systems. The APPEA Journal, 41, 15-35.

POWER, M.R., HILL, K.C. AND HOFFMAN, N. 2003-Structural inheritance, stress rotation and compressional reactivation in the Gippsland Basin-Tuna 3D seismic data set. The APPEA Journal, 43, Pt 1, 197-221.

PRAEG, D., STOKER, M.S., SHANON, P.M., CERAMICOLA, S., HJELSTUN, B.O. AND MATHIESEN, A. 2005- Episodic Cenozoic tectonism and the development of the NW European 'passive' continental margin. Marine and Petroleum Geology, 22, $1007-1030$. 
QUIGLEY, M., CUPPER, M. AND SANDIFORD, M., 2006-Quaternary faults of southern Australia: palaeoseismicity, slip rates and origin. Australian Journal of Earth Sciences, 53, 285-301

REYNOLDS, S.D., COBLENTZ, D.D. AND HILLIS, R.R., 2002-Tectonic forces controlling the regional intraplate stress field in continental Australia: results from new finite-element modelling. Journal of Geophysical Research, 107 (B7), 10.1029/2001JB000408.

SANDIFORD, M. 2003-Neotectonics of southeastern Australia: linking the Quaternary faulting record with seismicity and in situ stress. In: Hillis, R.R. and Muller, R.D. (eds) Evolution and dynamics of the Australian plate, GSA Special Publication 22 and GSAm Special Paper 372, 107-19.

SANDIFORD, M. 2007-The tilting continent: A new constrain on the dynamic topographic field from Australia. Earth and Planetary Science Letters, 261, 152-163, 10.1016/j.epsl.2007.06.023.

SANDIFORD, M. AND QUIGLEY, M. 2009-TOPO-OZ: Insights into the various modes of intraplate deformation in the Australian continent. Tectonophysics, 474, 405-416, 10.1016/j.tecto.2009.01.028.

SANDIFORD, M., WALLACE, M. AND COBLENTZ, D. 2004-Origin of the in situ stress field in southeastern Australia. Basin Research, 16, 325-38.

SANDIFORD, M., QUIGLEY, M., DE BROKERT, P. AND JAKICA, S. 2009-Tectonic framework for the Cenozoic cratonic basins of Australia. Australian Journal of Earth Sciences, 56, S5-S18.

SAYERS, J., SYMONDS, P.A., DIREEN, N.O. AND BERNARDEL, G. 2001- Nature of continent-ocean transition on the non volcanic rifted margin of the central Great Australian Bight. In:Wilson R.C.L., Whitmarsh, R.B., Taylor, B. and Froitzheim, N. (eds) Non-volcanic rifting of oceanic margins: a comparison of evidence from land and sea, GSL, Special Publication 187, 51-76.

SCHNEIDER, C.L., HILL, K.C. AND HOFFMAN, N., 2004-Compressional growth of the Minerva Anticline, Otway Basin, Southeast Australia-evidence of oblique rifting. The APPEA Journal, 44 (1), 463-80.

SHARP, N. C. AND WOOD, G. R. 2004-Casino Gas Field, offshore Otway Basin, Victoria-the appraisal story and some stratigraphic enlightenment. In: Boult, P.J., Johns, D.R. and Lang, S.C. (eds) Eastern Australian basins symposium II, PESA Special Publication, $1-11$.

STOKER, M.S., HOUlT, R.J., NIELSEN, T., HJELSTUN, B.O., LABERG, J.S., SHANNON, P.M., PRAEG, D., MATHIESEN, A., VAN WEERING, T.C.E. AND McDONNELL, A. 2005-Sedimentary and oceanographic responses to early Neogene compression on the NW European margin. Marine and Petroleum Geology, 22, 1031-1044.

SLEEP, N. 1971- Thermal effects of the formation of Atlantic continental margins by continental breakup. Geophysical Journal of the Royal Astronomical Society 24, 325-350.

TIKKU, A.A. AND CANDE, S.C. 1999-The oldest magnetic anomalies in the Australian-Antarctic Basin: Are they isochrons? Journal of Geophysical Research, 104 (B1), 661-677.

TOTTERDELL, J.M. AND BRADSHAW, B.E. 2004-The structural framework and tectonic evolution of the Bight Basin. In: Boult, P.J., Johns, D.R. and Lang, S.C. (eds) Eastern Australian basins symposium II, PESA Special Publication, $41-61$.

TRUPP, M.A., SPENCE, K.W. AND GIDDING, M.J. 1994-Hydrocarbon prospectivity of the Torquay Sub-Basin, Offshore Victoria. APEA Journal, 34, 479-494.

TURNER, J.P., GREEN, P.F., HOLFORD, S.P. AND LAWRENCE, S.R. 2008-Thermal history of the Rio Muni (West Africa)-NE Brazil margins during continental breakup. Earth and Planetary Science Letters, 270, 354-367.

VEEVERS, J.J. 2000-Billion-Year Earth History of Australia and Neighbours in Gondwanaland. GEMOC Press, Sydney.

WHITE, N., THOMPSON, M. AND BARWISE, T. 2003-Understanding the thermal evolution of deep-water continental margins. Nature, 426, 334-343.

WILSON, J.T. 1966-Did the Atlantic close and then re-open? Nature, 211, 676-681.

WOOLLANDS, M.A. AND WONG, D. 2001-Petroleum Atlas of Victoria, Australia. The State of Victoria, Department of Natural Resources and Environment. 


\section{FIGURE CAPTIONS}

\section{Figure 1}

Topography, bathymetry and neotectonics of the southern Australian continental margin. Regional maximum horizontal stress orientations modified after Hillis et al (2008b). Location of neotectonic fault scarps modified after Sandiford (2003), Hillis et al (2008b) and Holdgate et al (2008). Inferred position of early Miocene ( $15 \mathrm{Ma}$ ) shoreline modified after Veevers (2000). Earthquake epicentres were obtained from Geoscience Australia's earthquake database (Leonard 2008). The earthquakes shown occurred between 1900-2007 and represent a subset of the catalogue that has been filtered to meet national completeness levels and screened to remove aftershocks. Note distinct spatial partitioning of regions of elevated topography, abundant neotectonic structures and high seismicity such as the Flinders/Mt Lofty Ranges and southeastern Highlands, and regions of subdued topography, few structures and low seismicity such as the Bight/Eucla and Murray basins. Inset shows location of the Minerva and Nerita anticlines.

\section{Figure 2}

Detailed map showing locations of wells and seismic lines referred to in this study, and major structural elements of the Shipwreck Trough and Torquay sub-basin. Inset maps show two way travel time (seconds) to the intra-Oligocene unconformity around the Minerva and Nerita anticlines, which help delineate the orientations of these structures at that stratigraphic level (note extent of isochrons is dictated by the extent of 2D seismic reflection profiles used in seismic mapping).

\section{Figure 3}

Stratigraphy of the eastern Otway Basin and Torquay sub-basin. Modified after Constantine and Liberman (2001).

\section{Figure 4}

Uninterpreted (above) and interpreted (below) seismic reflection profile OE80A-1056 through the Minerva Anticline in the Shipwreck Trough, eastern Otway Basin. The structure is interpreted to be a late Cretaceous half-graben that has been inverted due to Cenozoic compression. Significant growth on the structure during the Neogene-Recent is witnessed by folding of the Top Nirranda Group intraOligocene unconformity. Seismic reflection data provided from the PGS Southern Australian Margin Digital Atlas (SAMDA) project.

\section{Figure 5}

Uninterpreted (above) and interpreted (below) seismic reflection profile O40-21A through the Nerita Anticline in the Torquay sub-basin. The structure is also interpreted to be a late Cretaceous-early Palaeogene half-graben that has been subsequently inverted to form a structural culmination. Little evidence for growth/thickness variations in the Demons Bluff Group across the structure indicates that deformation occurred during the Neogene-Recent, probably coeval with erosion that produced the 10-5 Ma Miocene-Pliocene unconformity. Seismic reflection data provided from the PGS Southern Australian Margin Digital Atlas (SAMDA) project.

\section{Figure 6}

Thermal history reconstruction for the Minerva-1 well, indicating that the preserved section is at maximum post-depositional temperatures at the present-day and thus source rock maturation post-dates trap formation, and showing two burial and thermal scenario scenarios that are consistent with the measured AFTA and VR data. a) Plot of palaeotemperatures derived from AFTA and VR data in the Minerva-1 well, against depth and the estimated present temperature profile for this well. b) Crossplot of allowed (but not required) total section removed from the top-Heytesbury Group unconformity in the Minerva-1 well against palaeogeothermal gradient. c) Scenario 1 burial history that is consistent with the simplest interpretation of the AFTA and VR results, assuming constant heat flow with progressive burial of the late Cretaceous-Cenozoic section, and without significant uplift and erosion on any unconformity. d) Scenario 1 thermal history based on the primary interpretation of the AFTA and VR results, which strongly suggest that the sampled Cretaceous section is at, or very close to, maximum post-depositional temperatures at the present-day. This history has been used to reconstruct the burial history shown in c) and incorporates a constant palaeogeothermal gradient of $42.2^{\circ} \mathrm{C} \mathrm{km}^{-1}$ (equal to the present-day level) and a constant palaeo sea-bed temperature of $15^{\circ} \mathrm{C}$. e) Scenario 2 burial history that is consistent with the best-fit interpretation of the AFTA and VR results, with progressive burial of the late Cretaceous-Cenozoic section with maximum burial in the mid-Miocene followed by 350 of uplift and erosion between 10 and 5 Ma. f) Scenario 2 thermal history that is allowed by quantitative analysis of the AFTA and VR results, which allow a minor cooling episode within the last $50 \mathrm{Ma}$. This history is based on the best fit estimate of palaeogeothermal gradient (b) and incorporates a gradient of $35^{\circ} \mathrm{C} \mathrm{km}^{-1}$ until $2 \mathrm{Ma}$ increasing progressively to $42.2^{\circ} \mathrm{C} \mathrm{km}^{-1}$ at the present-day with $10^{\circ} \mathrm{C}$ of cooling between 10 and $5 \mathrm{Ma}$ in order to match the palaeotemperature constraints.

\section{Figure 7}

Thermal history reconstruction for the Nerita-1 well, indicating that the preserved section most likely cooled from maximum postdepositional temperatures prior to late Miocene-Recent trap formation (Scenario 1) and that potential underlying source rocks may have cooled from maximum palaeotemperatures prior to mid-Cretaceous uplift and erosion (Scenario 2). a) Plot of palaeotemperatures derived from AFTA, VR and apatite (U-Th)/He data in the Nerita-1 well against depth and the estimated present temperature profile for this location. b) Crossplot of total section removed from the top-Torquay Group unconformity in the Nerita-1 well against palaeogeothermal gradient as required by the AFTA, (U-Th)/He and selected VR results. The plot shows the range of values compatible with the maximum palaeotemperatures the $95 \%$ confidence level. For a palaeogeothermal gradient of $31.5^{\circ} \mathrm{C} \mathrm{km}^{-1}$, equal to the present-day value, between 
940-1260 m of removed section is required on the top-Torquay Group unconformity in order to honour the palaeotemperature constraints. c) Scenario 1 burial history reconstructed on the basis of the preferred thermal history reconstruction based on available data from Nerita-1 (shown in d). This burial history incorporates $1050 \mathrm{~m}$ of additional section attributed to the Miocene Puebla Formation subsequently removed by uplift and erosion beginning at $8 \mathrm{Ma}$ and completed prior to the Pliocene. d) Scenario 1 reconstructed thermal history. This history incorporates a constant palaeogeothermal gradient of $31.5^{\circ} \mathrm{C} \mathrm{km}^{-1}$ (equal to the present-day level) and a constant palaeo-sea bed temperature of $15^{\circ} \mathrm{C}$, as allowed by the quantitative analysis of the data. e) Scenario 1 burial history reconstructed on the basis of regional thermal history results (cf Green et al 2004) (underlying thermal history shown in f). This burial history incorporates the same late Miocene event as shown in c), together with $1200 \mathrm{~m}$ of section removed on the top-Otway Group unconformity, in accord with regional geological and thermal history constraints. f) Scenario 2 thermal history incorporating a mid-Cretaceous thermal episode based on regional data (e.g. AFTA and VR from Anglesea-1) with the results obtained from the Nerita-1 drilled section shown in e). This history incorporates a palaeogeothermal gradient rising from $31.5^{\circ} \mathrm{C} \mathrm{km}^{-1}$ (equal to the present-day level) at $140 \mathrm{Ma}$ to $51^{\circ} \mathrm{C} \mathrm{km}^{-1}$ at $95 \mathrm{Ma}^{\mathrm{M}}$ following which it declines to $31.5^{\circ} \mathrm{C} \mathrm{km}^{-1}$ at $80 \mathrm{Ma}$ and remains constant at that level to the present day. A constant palaeo-sea bed temperature of $15^{\circ} \mathrm{C}$ is assumed. The red and green columns represents the 10 to $5 \mathrm{Ma}$ time period in which cooling of the preserved section cooling began and the 100 to 90 Ma time period defining the mid-Cretaceous thermal episode from regional data.

\section{Table 1}

Sample details, data and palaeotemperature analysis summary for Minerva-1.

\section{Table 2}

Sample details, data and palaeotemperature analysis summary for Nerita-1. 


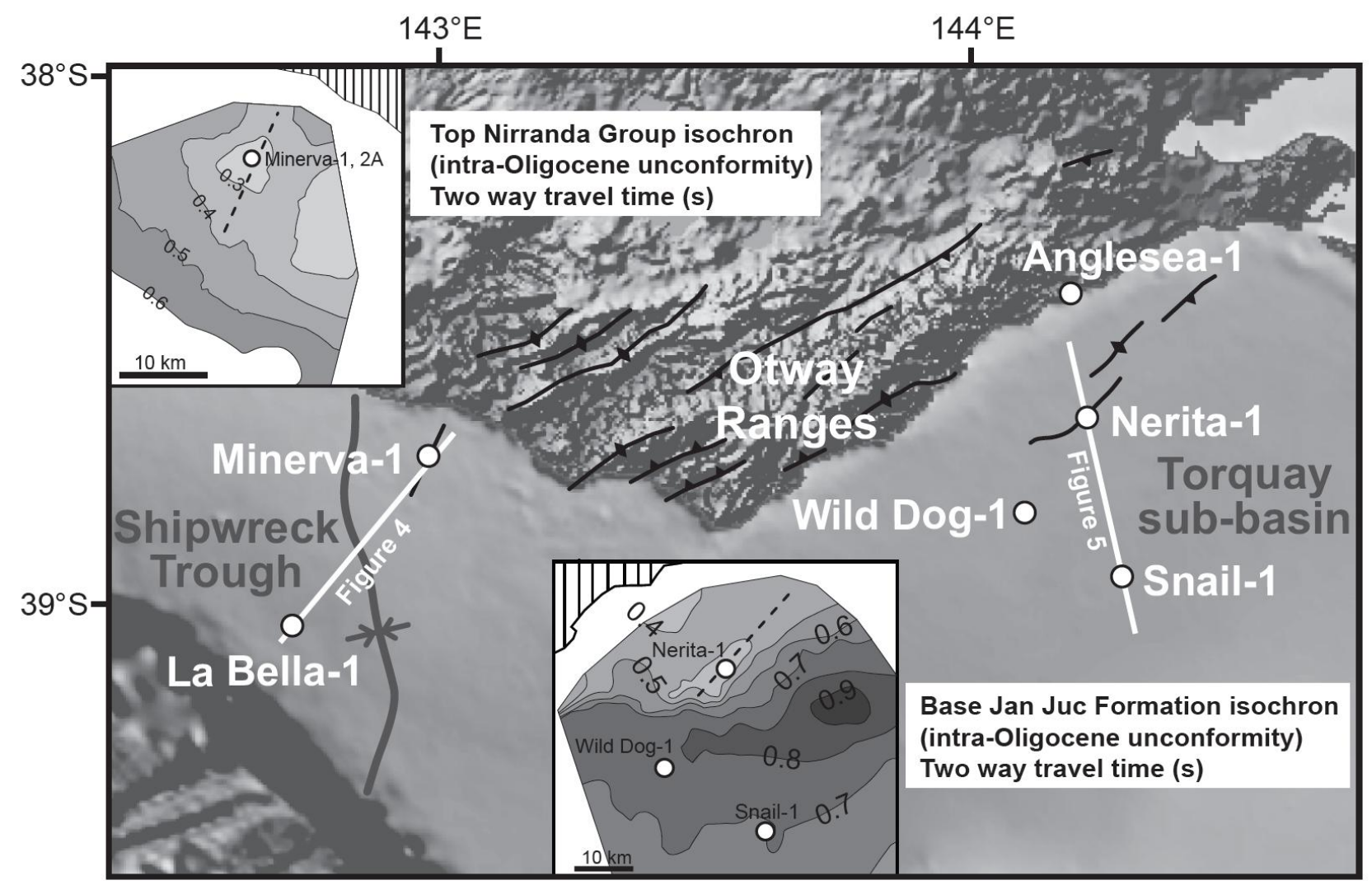



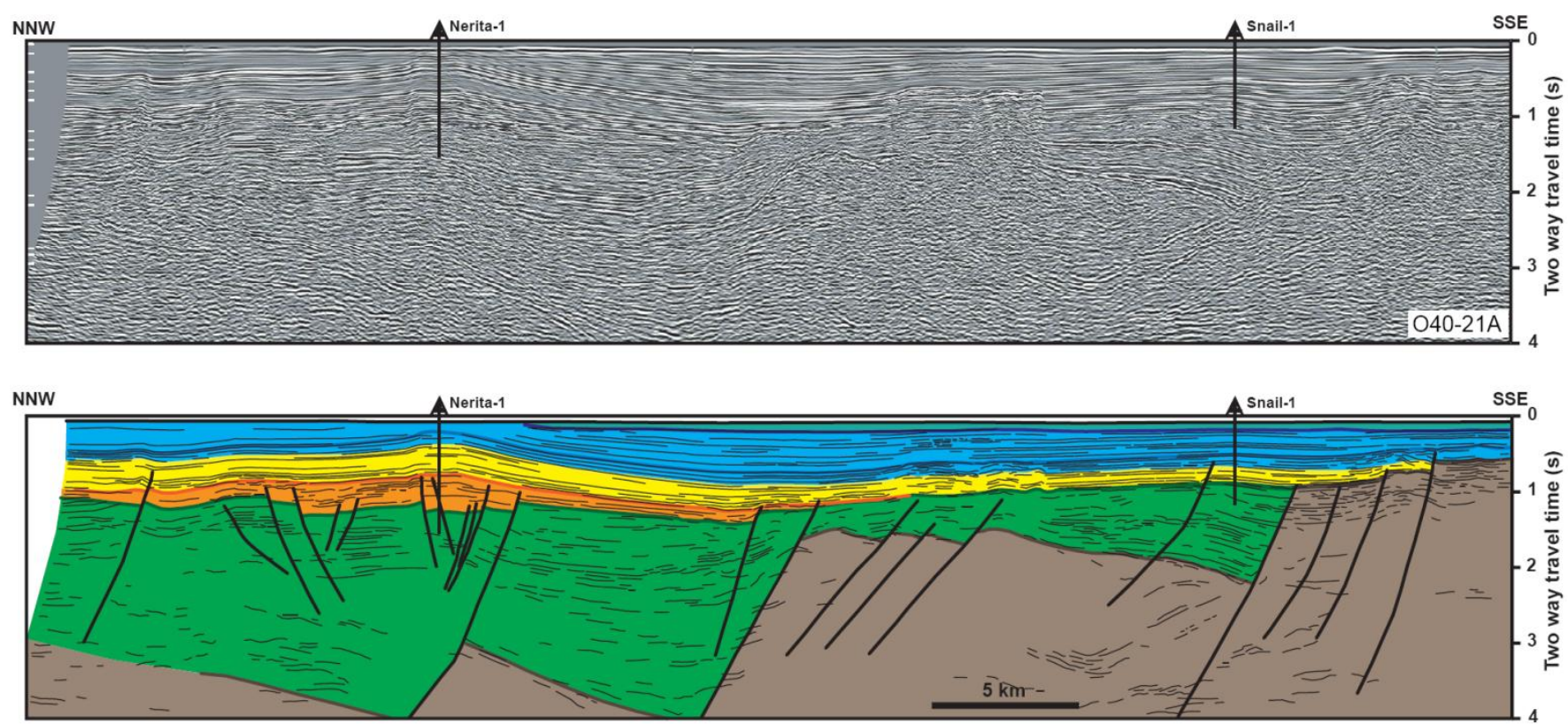

Miocene-Pliocene unconformity Top Jan Juc Formation (late Chattian) Intra-Oligocene unconformity

Intra-Lutetian unconformity

Mid-Cretaceous unconformity

Top Basemen

Brighton Group (Pliocene-Pleistocene)

Torquay Group (Rupelian-Messinian)

Demons Bluff Group (Lutetian-Rupelian)

Eastern View Group (Campanian-Lutetian)

Otway Group (Tithonian-Albian)

Basement (Silurian) 

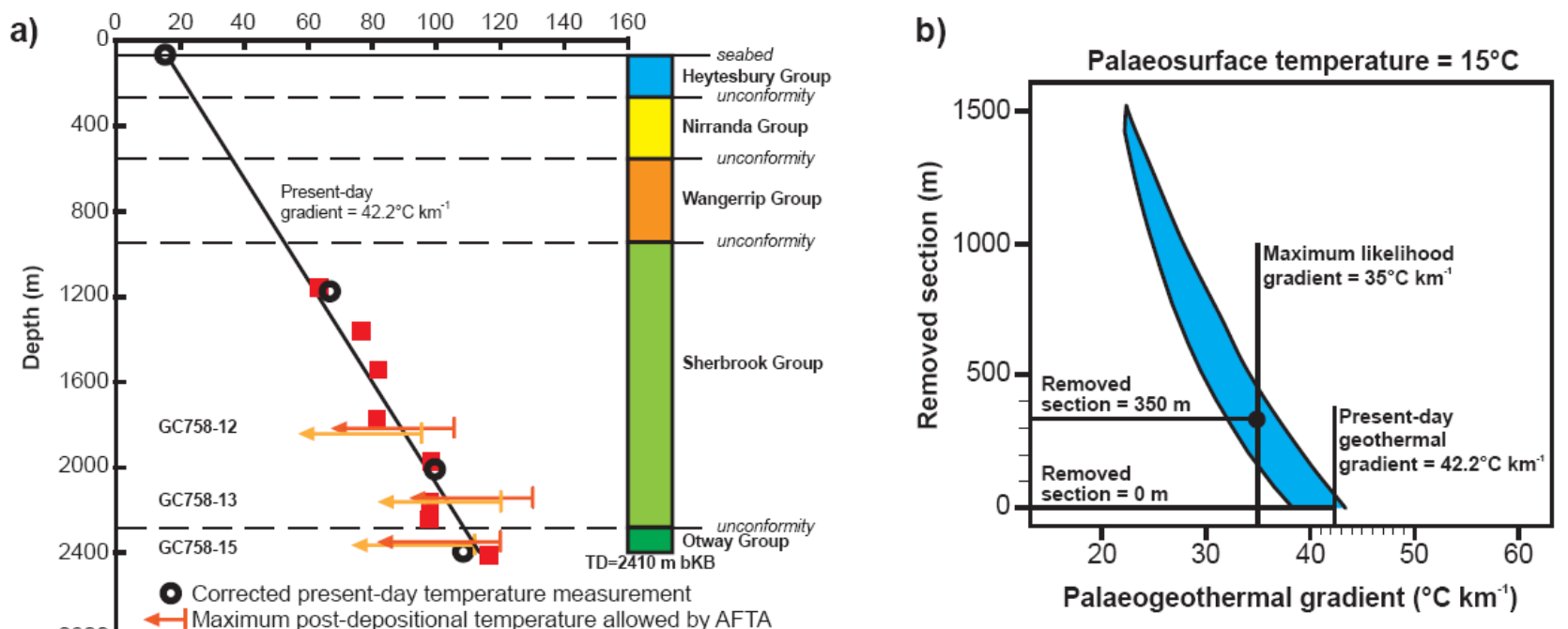

2800 Maximum palaeotemperature allowed by AFTA between 50 and $0 \mathrm{Ma}$

Maximum palaeotemperature from VR data

\section{Scenario 1 - constant heat flow}

c)

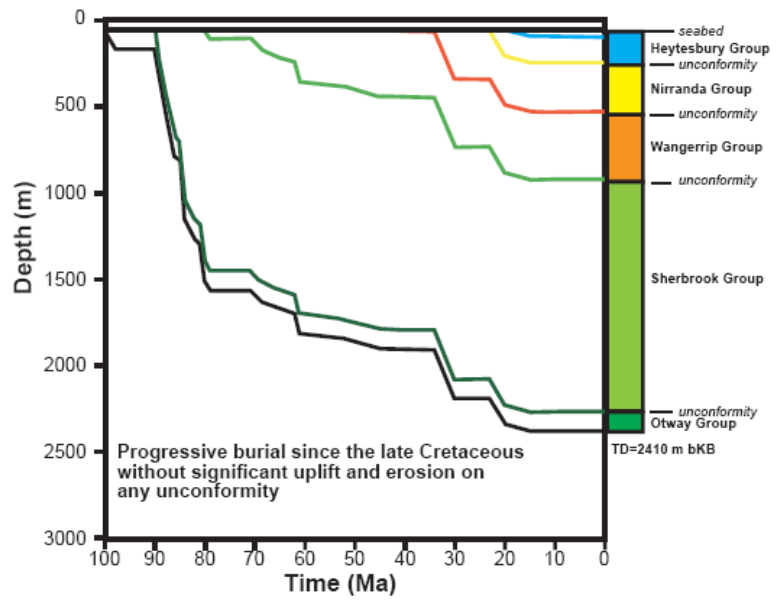

d)

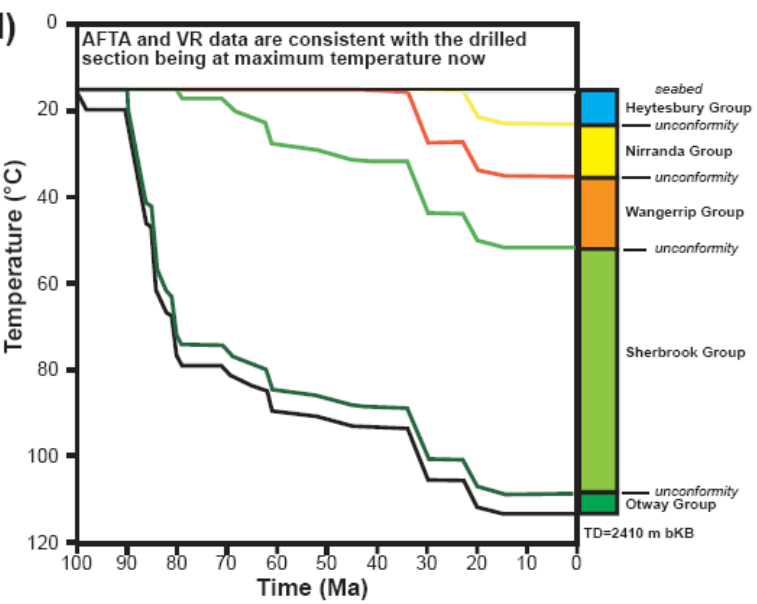

Scenario 2 - recent increase in heat flow

e)

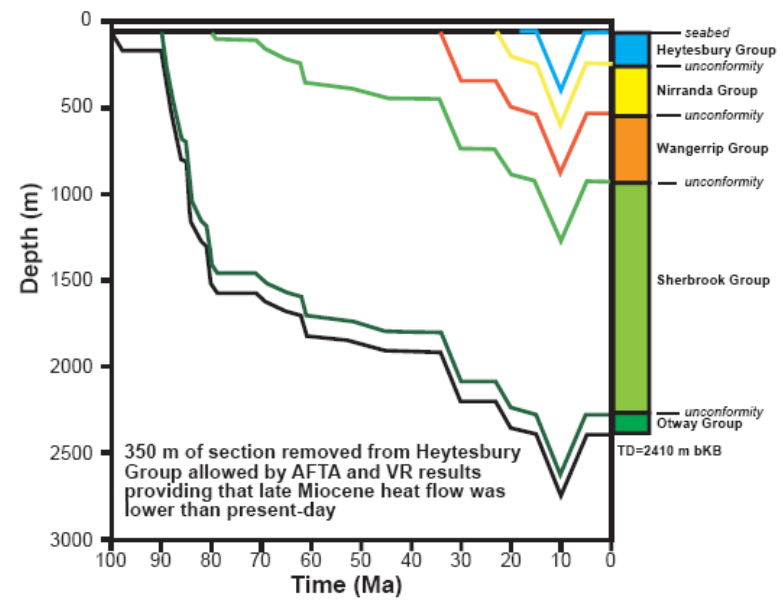

f)

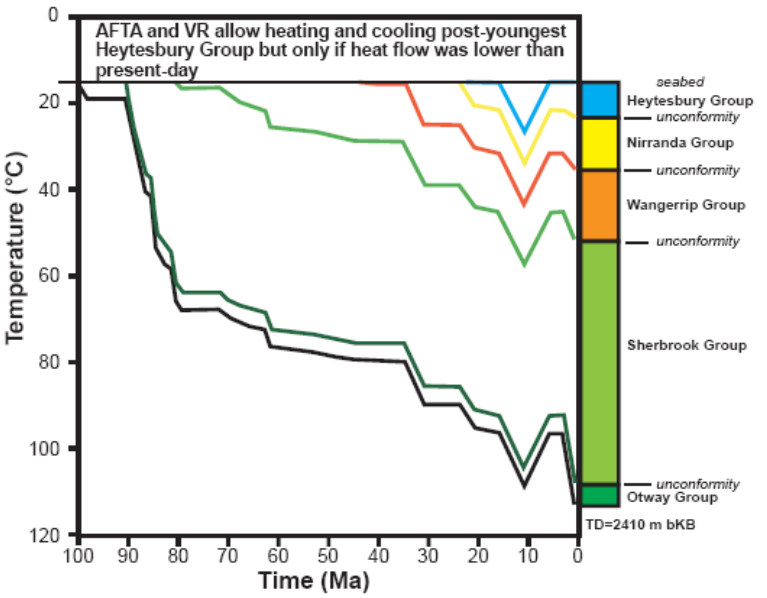


a)

Temperature $\left({ }^{\circ} \mathrm{C}\right)$

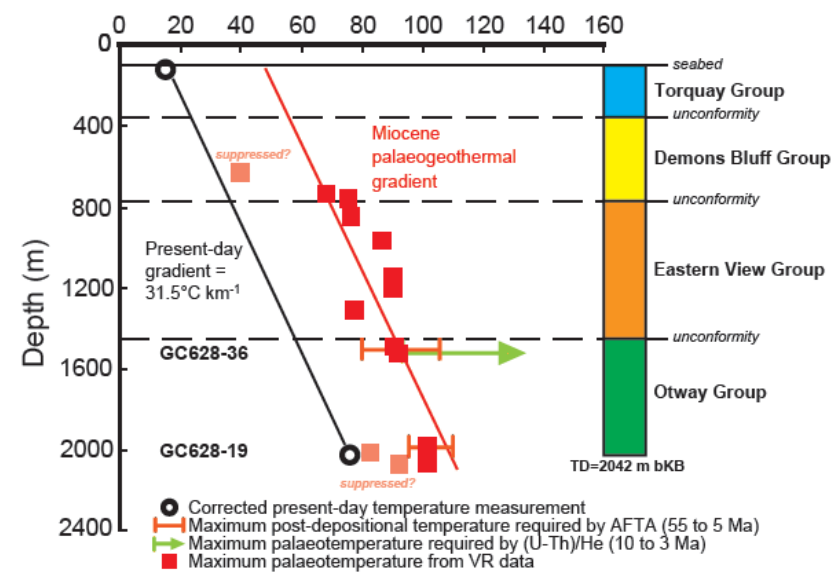

b)

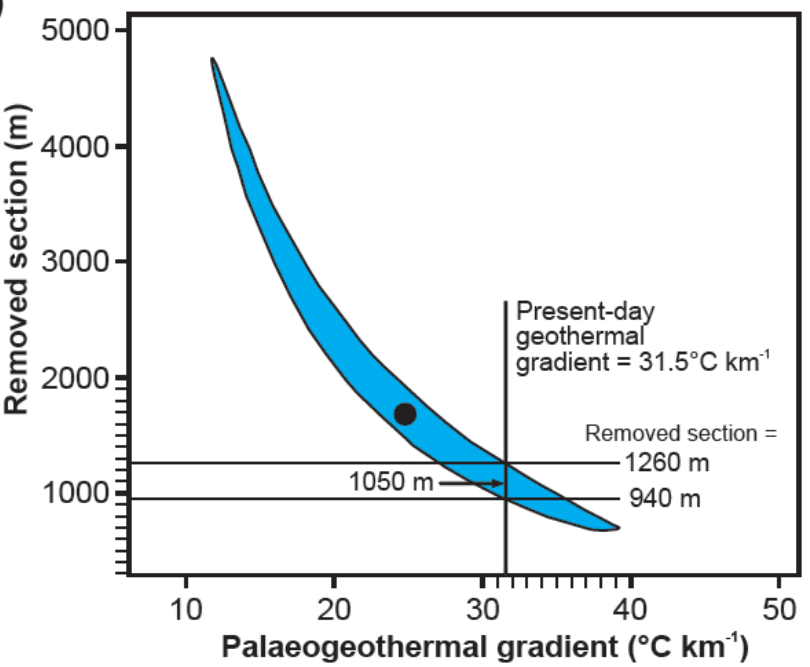

\section{Scenario 1 - reconstructions based on data from Nerita-1 only}

c)

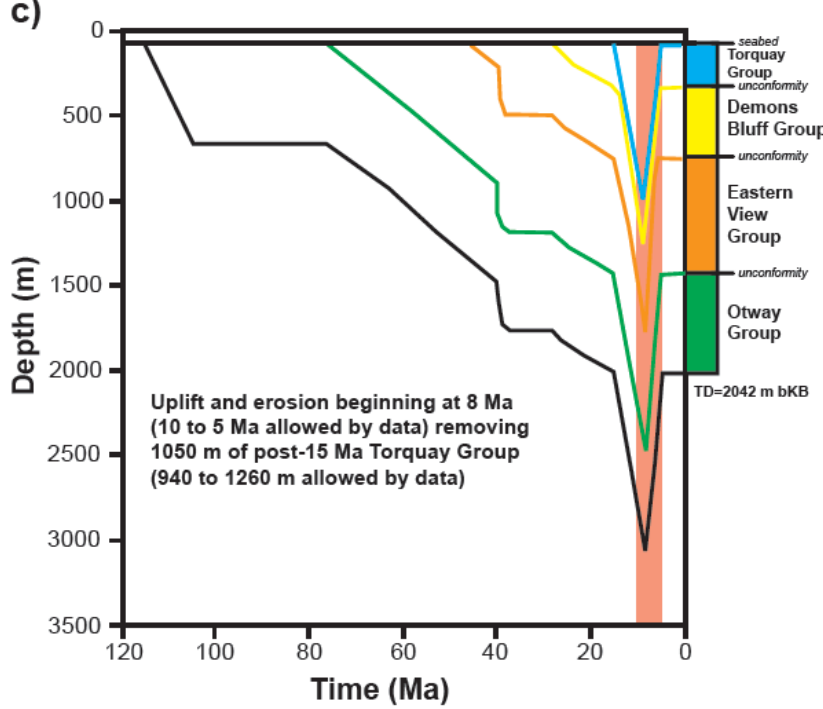

d)

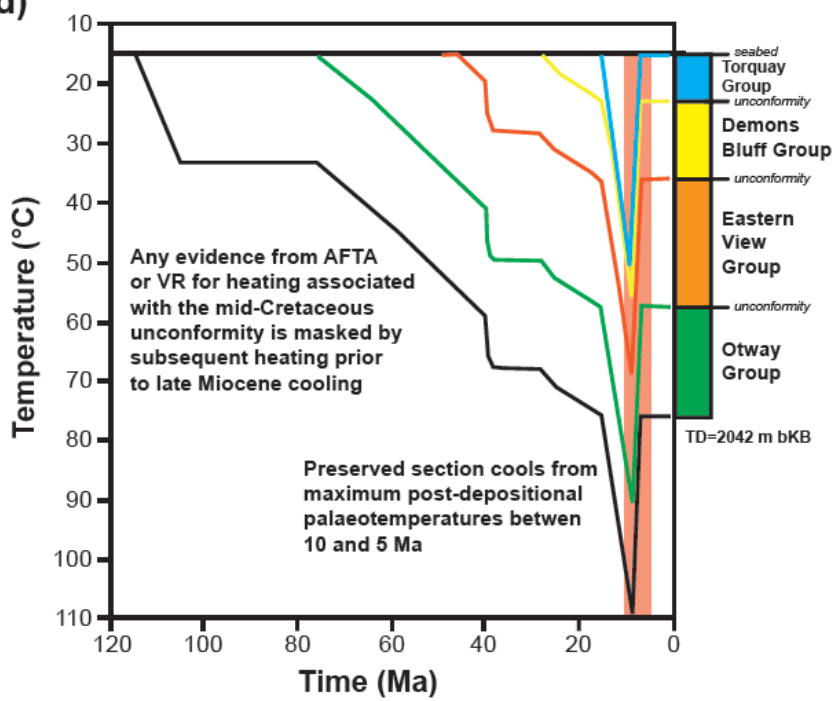

Scenario 2 - reconstructions based on regional data
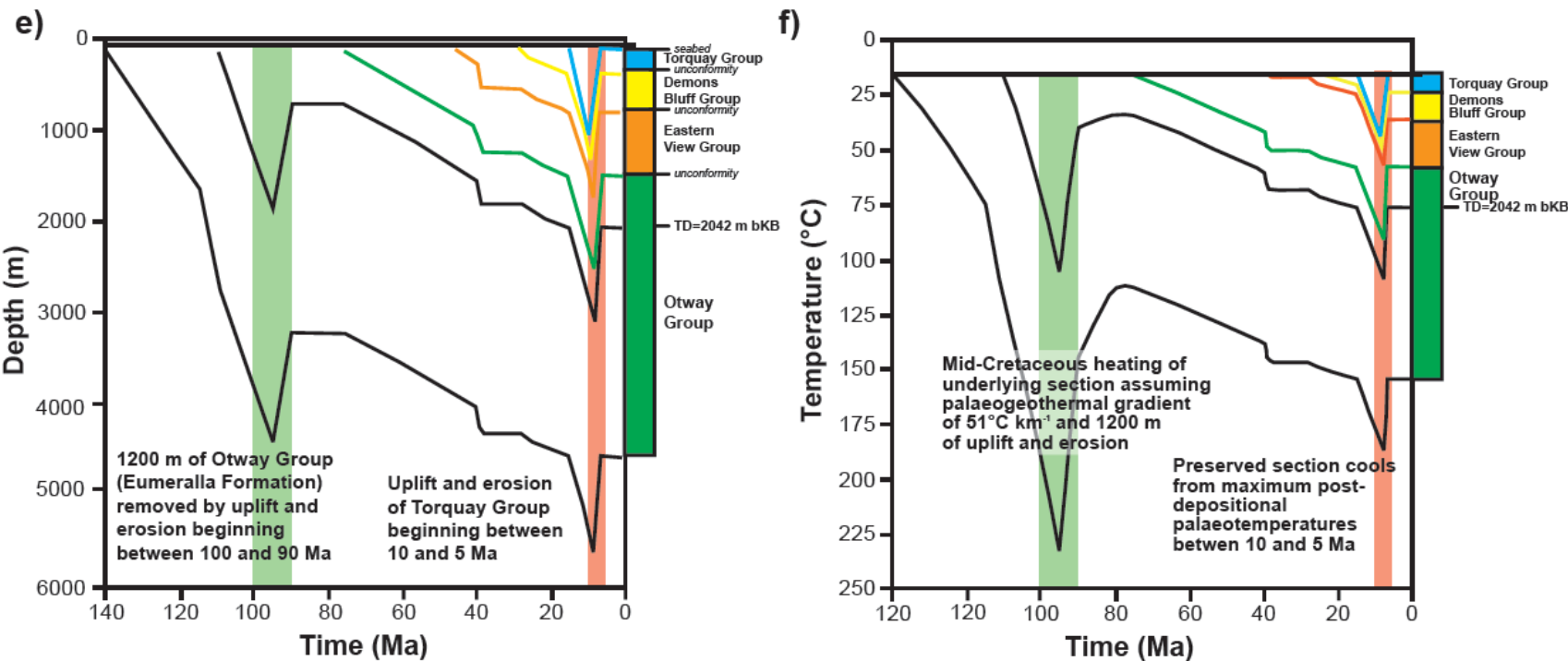
Table 1. Sample details, data and palaeotemperature analysis summary for Minerva-1

\begin{tabular}{|c|c|c|c|c|c|c|c|c|c|c|c|}
\hline \multicolumn{12}{|c|}{ Apatite fission track analysis (AFTA) samples } \\
\hline $\begin{array}{l}\text { Sample } \\
\text { number }\end{array}$ & $\begin{array}{c}\text { Depth } \\
\text { (mTVD KB) }\end{array}$ & $\begin{array}{c}\text { Present } \\
\text { temperature } \\
\left({ }^{\circ} \mathrm{C}\right)^{*}\end{array}$ & Stratigraphic subdivision & $\begin{array}{l}\text { Stratigraphic } \\
\text { age (Ma) }\end{array}$ & $\begin{array}{l}\text { Fission track } \\
\text { age }(\mathrm{Ma}) \dagger, \sharp\end{array}$ & $\begin{array}{l}P\left(\chi^{2}\right) \\
(\%)\end{array}$ & $\begin{array}{l}\text { Mean track } \\
\text { length }(\mu \mathrm{m}) \dagger\end{array}$ & $\begin{array}{c}\text { Maximum } \\
\text { palaeotemperature } \\
\left({ }^{\circ} \mathrm{C}\right) \S\end{array}$ & $\begin{array}{c}\text { Onset of } \\
\text { cooling (Ma) } \S\end{array}$ & $\begin{array}{c}\text { Maximum } \\
\text { palaeotemperature } \\
\left({ }^{\circ} \mathrm{C}\right) \S\end{array}$ & $\begin{array}{c}\text { Onset of } \\
\text { cooling (Ma) § }\end{array}$ \\
\hline GC758-12 & $1821-1847$ & 89 & $\begin{array}{c}\text { Sherbrook Group } \\
\text { (Waarre Formation) }\end{array}$ & $89-87$ & $128.1 \pm 22.7(19)$ & $<1$ & $9.79 \pm 0.23(56)$ & $<105$ & Post-deposition & $<95$ & $50-0$ \\
\hline GC758-13 & $2102-2201$ & 102 & $\begin{array}{l}\text { Sherbrook Group (Copa } \\
\text { Formation) }\end{array}$ & $90-89$ & $111.3 \pm 31.1(8)$ & $<1$ & $12.78 \pm 0.47(10)$ & $<130$ & Post-deposition & $<120$ & $50-0$ \\
\hline GC758-15 & $2294-2426$ & 111 & $\begin{array}{l}\text { Otway Group (Eumeralla } \\
\text { Formation) } \\
\end{array}$ & $100-98$ & $49.5 \pm 11.8(14)$ & $<1$ & $8.50 \pm 2.00(3)$ & $<120$ & Post-deposition & $<112$ & $50-0$ \\
\hline \multicolumn{12}{|c|}{ Vitrinite reflectance (VR) samples } \\
\hline $\begin{array}{l}\text { Sample } \\
\text { number }\end{array}$ & $\begin{array}{c}\text { Depth } \\
\text { (mTVD KB) }\end{array}$ & $\begin{array}{c}\text { Present } \\
\text { temperature } \\
\left({ }^{\circ} \mathrm{C}\right)^{*}\end{array}$ & Stratigraphic subdivision & $\begin{array}{l}\text { Stratigraphic } \\
\text { age (Ma) }\end{array}$ & $R_{\mathrm{o}} \max$ & $\mathrm{N}$ & Range & $\begin{array}{c}\text { Maximum } \\
\text { palaeotemperature } \\
\left({ }^{\circ} \mathrm{C}\right) \S \\
\end{array}$ & & & \\
\hline v7853 & 1130 & 59 & $\begin{array}{l}\text { Sherbrook Group } \\
\text { (Skull Creek Mdst) }\end{array}$ & $82-80$ & 0.42 & 29 & $0.29-0.57$ & 61 & & & \\
\hline v7854 & 1342 & 68 & $\begin{array}{l}\text { Sherbrook Group } \\
\text { (Belfast Mdst) }\end{array}$ & $85-84$ & 0.50 & 12 & $0.42-0.57$ & 74 & & & \\
\hline v7855 & 1523 & 76 & $\begin{array}{l}\text { Sherbrook Group } \\
\text { (Belfast Mdst) }\end{array}$ & $85-84$ & 0.53 & 28 & $0.41-0.64$ & 79 & & & \\
\hline v7856 & 1747 & 85 & $\begin{array}{l}\text { Sherbrook Group } \\
\text { (Flaxman Formation) }\end{array}$ & $87-86$ & 0.53 & 15 & $0.40-0.74$ & 79 & & & \\
\hline v7857 & 1948 & 94 & $\begin{array}{l}\text { Sherbrook Group } \\
\text { (Waarre Formation) }\end{array}$ & $89-87$ & 0.63 & 26 & $0.53-0.71$ & 96 & & & \\
\hline v7858 & 2158 & 103 & $\begin{array}{l}\text { Sherbrook Group (Copa } \\
\text { Formation) }\end{array}$ & $90-98$ & 0.62 & 27 & $0.57-0.71$ & 95 & & & \\
\hline v7859 & 2215 & 105 & $\begin{array}{l}\text { Sherbrook Group (Copa } \\
\text { Formation) }\end{array}$ & $90-98$ & 0.62 & 2 & $0.57-0.67$ & 95 & & & \\
\hline v7860 & 2393 & 113 & $\begin{array}{c}\text { Otway Group (Eumeralla } \\
\text { Formation) }\end{array}$ & $100-98$ & 0.75 & 9 & $0.60-0.94$ & 114 & & & \\
\hline
\end{tabular}

*Present-day temperature calculated using present-day geothermal gradient derived from corrected BHT data cited in text.
†Numbers in brackets following fission track age and mean track length represent the number of single grain ages and track lengths measured.

$\$$ Central age (Galbraith and Laslett, 1993) used for samples containing a significant spread in single grain ages $\left[P\left(\chi^{2}\right)<5 \%\right]$, otherwise the 'pooled age' is quoted. All ages were calculated using the $\zeta$ calibration approach of Hurford and Green (1983)

and CN5 dosimeter glass, using a $\zeta$ of $392.9 \pm 7.4$ (Analyst: M. Moore). All errors quoted at $\pm 1 \sigma$.

characterizing both AFT A and VR, increasing or decreasing heating rates by an order of magnitude is equivalent to raising or lowering the maximum paleotemperature by about $10^{\circ} \mathrm{C}$. The kinetic model of Burnam and Sweeney (1989) was used

for VR data. 
Table 2. Sample details, data and palaeotemperature analysis summary for Nerita-1.

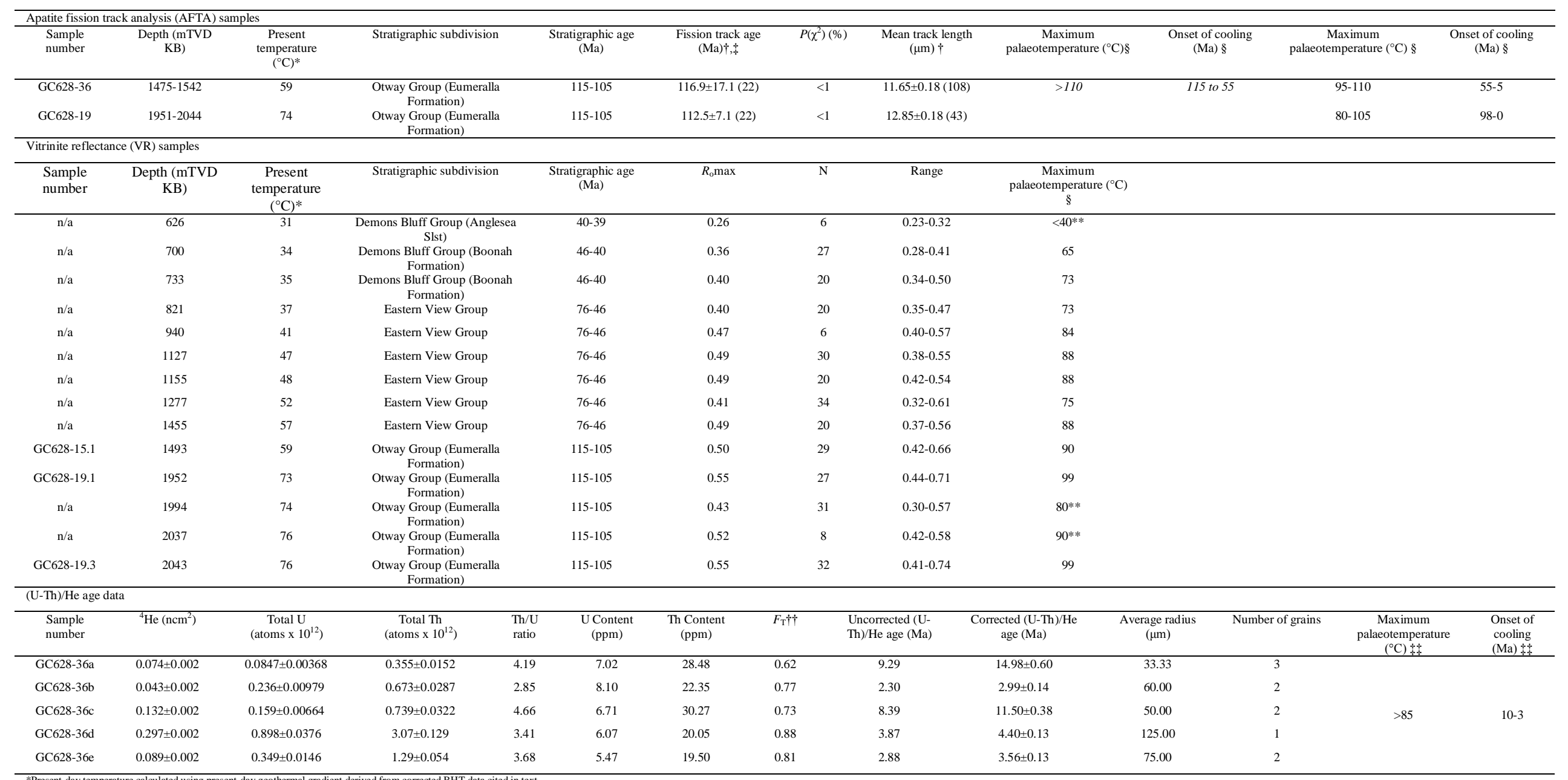

*Present-day temperature calculated using present-day geothermal gradient derived from corrected BHT data cited in text.

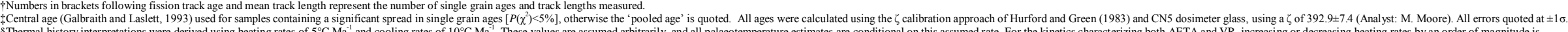

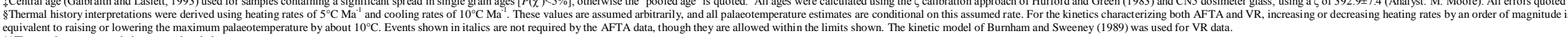
These values are regarded as anomalously low

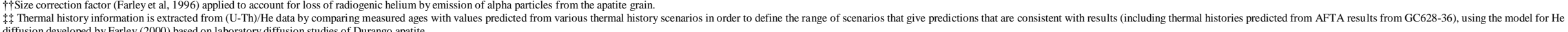

